\title{
Physiological and Agronomical Aspects of Phytohormone Production by Model Plant-Growth-Promoting Rhizobacteria (PGPR) Belonging to the Genus Azospirillum
}

\author{
Fabricio Cassán • Jos Vanderleyden • \\ Stijn Spaepen
}

Received: 24 January 2013/Accepted: 4 June 2013/Published online: 10 August 2013

(c) Springer Science+Business Media New York 2013

\begin{abstract}
The functional analysis of phytohormone production, interaction, and regulation in higher plants has reemerged in the past 10 years due to spectacular advances in integrative study models. However, plants are not axenic in natural conditions and are usually colonized or influenced directly by different microorganisms such as rhizobacteria of which many have the ability to produce phytohormones. This review summarizes information related to the biosynthesis, metabolism, regulation, physiological role, and agronomical impact of phytohormones produced by the model plant-growth-promoting rhizobacteria (PGPR) belonging to the genus Azospirillum, considered to be one of the most representative PGPR. We include exhaustive information about the phytohormones auxins, gibberellins, cytokinins, ethylene, and abscisic acid, as well as the plant growth regulators polyamines and nitric oxide. We deal with their metabolism by Azospirillum sp. in chemically defined medium, in plant-microbe interactions, or in the context of the agronomical use of Azospirillum sp.
\end{abstract}

Keywords Auxins - Gibberellins · Cytokinins · Abscisic acid · Ethylene $\cdot$ Inoculants

F. Cassán $(\bowtie)$

Laboratorio de Fisiología Vegetal y de la Interacción planta-microorganismo, Universidad Nacional de Río Cuarto, Campus Universitario, CP 5800 Río Cuarto, Córdoba, Argentina e-mail: fcassan@exa.unrc.edu.ar

J. Vanderleyden $\cdot$ S. Spaepen

Centre of Microbial and Plant Genetics, KU Leuven, Kasteelpark

Arenberg 20, Bus 2460, 3001 Heverlee, Belgium

\section{Rhizosphere and Rhizobacteria}

The term rhizosphere is used to describe the portion of soil in which growth of microorganisms is influenced by the presence of the root system (Hartmann and others 2008). The rhizosphere bacteria, so-called rhizobacteria, can be divided into those that form a symbiotic relationship with the plants and those that do not. The latter, called freeliving, are closely associated with the root surface or reside within the roots as endophytic bacteria (Kloepper and others 1989). When the presence of rhizobacteria benefits plant growth, those rhizobacteria are called plant-growth-promoting rhizobacteria (PGPR). The vast group of rhizobacteria was divided into different subgroups according to the bacterial promotion mechanisms used during interactions. These subgroups include (1) the PGPR group, proposed by Kloepper and Schroth (1978); (2) the biocontrol-plantgrowth-promoting bacteria (biocontrol-PGPB) group, proposed by Bashan and Holguín (1998); and the (3) plant stress homeostasis-regulating rhizobacteria (PSHR) group, proposed by Cassán and others (2009a). However, due to the overlap of these functional subgroups, a clear classification is unrealistic. All PGPR either directly or indirectly facilitate or promote plant growth under nutritional, biotic (biocontrol-PGPB), or abiotic stress conditions. Indirect plant growth promotion induced by biocontrol-PGPB includes a variety of mechanisms, such as rhizosphere competition, induced systemic resistance (ISR), biosynthesis of stress-related phytohormones like jasmonic acid (JA) or ethylene, and biosynthesis of antimicrobial molecules, by which bacteria prevent the deleterious effects of phytopathogens on plant growth. Direct growth-promotion mechanisms induced by PGPR include biological nitrogen fixation, production of phytohormones such as auxins, gibberellins (GAs), cytokinins (CK), and nitric oxide (NO), 
iron sequestration by siderophores, and phosphate solubilization. Indirect plant growth promotion and regulation induced by PSHR includes production of stress-related phytohormones or plant growth regulators such as abscisic acid (ABA), JA, cadaverine (Cad), or the ethylene catabolism-related enzyme 1-aminocyclopropane-1-carboxylate (ACC) deaminase.

\section{Azospirillum sp. as Model of Plant-Growth-Promoting Rhizobacteria}

The Azospirillum genus is able to colonize more than a hundred plant species and to significantly improve plant growth, development, and productivity under agronomic conditions (Bashan and de Bashan 2010). One of the main mechanisms to explain plant growth promotion of inoculated plants has been related to the ability of Azospirillum to produce and metabolize several phytohormones and other plant growth regulatory molecules (Tien and others 1979). As a starting point for this review, we describe the phytohormones in Azospirillum sp. that have been studied in the past three decades because (1) a considerable number of molecules have been identified that could be responsible for modifying plant growth and architecture; (2) genes responsible for the synthesis of these compounds and their regulation have been identified; (3) growth responses of inoculated plants have been correlated with the levels of phytohormones measured in the culture medium, rhizosphere, or colonized plant tissues; (4) it has been shown that plant responses to exogenous application of phytohormones can be mimicked by bacterial inoculation; and (5) there is evidence that mutant bacterial strains with altered phytohormone production have different effects on plant hormone balance and growth promotion compared to isogenic strains, and this under a variety of experimental conditions.

\section{Phytohormone Production by Azospirillum sp.}

Although many mechanisms have been described to explain plant growth promotion by Azospirillum sp., a single mechanism is not responsible for the full effect. Multiple mechanisms rather than just one mechanism participate in the association of Azospirillum with plants; this hypothesis was suggested 20 years ago as the "additive hypothesis" (Bashan and Levanony 1990; Bashan and de Bashan 2010). One of the main mechanisms proposed to explain the "additive hypothesis" is related to the ability of bacteria to produce or metabolize phytohormones (Tien and others 1979; Okon and Labandera-González 1994). Based on the available data, Azospirillum sp. can be linked to the production of several hormonal groups such as auxins (Prinsen and others 1993), gibberellins (GAs) (Bottini and others
1989), cytokinins (CKs) (Tien and others 1979), ethylene (Et) (Strzelczyk and others 1994), abscisic acid (ABA) (Cohen and others 2008), and other plant growth regulators such as nitric oxide (NO) (Creus and others 2005) and polyamines (Cassán and others 2009a).

The following sections contain exhaustive information about the biosynthesis, metabolism, regulation, physiological role, and agronomical impact of phytohormonal compounds produced by Azospirillum sp. in chemically defined medium or during plant-microbe interactions.

\section{Auxins}

Auxin is the generic name that represents a group of chemical compounds characterized by their ability to induce cell elongation in the subapical region of the stem and to reproduce the physiological effect of the most abundant, naturally occurring auxin molecule, indole-3-acetic acid (IAA). These compounds have been associated with different plant processes such as (a) gravitropism and phototropism, (b) vascular tissue differentiation, (c) apical dominance, (d) lateral and adventitious root initiation, (e) stimulation of cell division, and (f) stem and root elongation (Teale and others 2006).

\section{Auxins and Biological Activity}

Several molecules are classified as auxins, but IAA is one of the most prevalent and active in biological systems. Other molecules, including indole-3-butyric acid (IBA) and phenylacetic acid (PAA), in addition to the precursor indole-3-acetonitrile (IAN), are considered active auxins. A variety of inactive molecules, including IAA halogenate compounds such 4-chloroindole-3-acetic acid and conjugated forms with sugars, alcohols, amino acids and glycoproteins, have been identified in plants and bacteria (Glick and others 1999; Korasick and others 2013).

\section{Auxins and Azospirillum sp.}

Members of the genus Azospirillum have provided an excellent experimental model for investigating and understanding the physiological and molecular role of auxins in plants and microbes and also in rhizobacteria-plant interactions. Several naturally occurring auxin-like molecules have been described as products of bacterial metabolism in Azospirillum sp. cultures (Fig. 1). In addition to IAA (between 5 and $50 \mu \mathrm{g} \mathrm{ml}^{-1}$ typically produced according to culture conditions and strain), IBA (Martínez-Morales and others 2003), and PAA (Somers and others 2005), considered in sensu stricto as real auxins, many other indolic compounds (precursors and/or catabolites) have been identified in Azospirillum sp. supernatants, including indole-3-lactic acid 
<smiles>O=C(O)Cc1c[nH]c2ccccc12</smiles>

indole-3-acetic acid<smiles>NC(=O)Cc1c[nH]c2ccccc12</smiles>

indole-3-acetamide<smiles>COC(=O)c1ccccc1N</smiles>

anthranilate

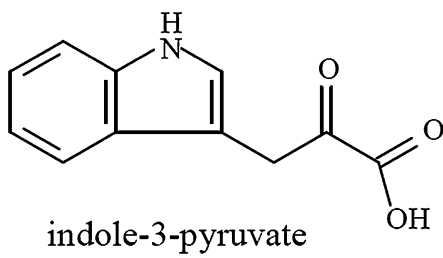<smiles>NC(Cc1c[nH]c2ccccc12)C(=O)O</smiles><smiles>O=C(O)CCCc1c[nH]c2ccccc12</smiles>

indole-3-butyric acid<smiles>O=CCc1c[nH]c2ccccc12</smiles>

indole-3-acetaldehyde<smiles>CC(C)(C)C(C)(C)C(C)(C)C</smiles><smiles>NCCc1c[nH]c2ccccc12</smiles><smiles>O=C(O)Cc1ccccc1</smiles>

phenylacetic acid<smiles>OCCc1c[nH]c2ccccc12</smiles>

indole-3-ethanol<smiles>N#CCc1c[nH]c2ccccc12</smiles>

indole-3-acetonitrile<smiles>O=C(O)C(O)Cc1c[nH]c2ccccc12</smiles>

\section{L-tryptophan}

Fig. 1 Chemical structure of the natural auxins (a), auxin-like molecules (b), and main precursor tryptophan for IAA biosynthesis (c) identified and reported in Azospirillum sp.

(ILA), indole-3-ethanol and indole-3-methanol (Crozier and others 1988), indole-3-acetamide (IAM) (Hartmann and others 1983), indole-3-acetaldehyde (Costacurta and others 1994), tryptamine (TAM), anthranilate, and other uncharacterized indolic compounds (Hartmann and others 1983). The physiological function of most of these compounds remains unknown, although many of them may serve as precursors or storage compounds for IAA.

\section{IAA and Bacterial Biosynthesis}

At least six metabolic routes for IAA biosynthesis have been proposed in bacteria and most of them use tryptophan (Trp) as a precursor. The pathways have been named mostly according to their intermediates such as indole-3pyruvate (IPyA), indole acetamide (IAM), TAM, and IAN; however, one pathway was named for the key enzyme tryptophan side-chain oxidase (TSO). In addition, a tryptophan-independent pathway has been suggested. Despite this diversity of pathways to produce the active phytohormone, prokaryotic IAA biosynthesis seems to follow predominantly two major routes: the IAM and the IPyA pathways (Lambrecht and others 2000).

\section{Azospirillum sp. and IAA Biosynthesis}

Until now, at least four different pathways have been proposed/described for this genus, three Trp-dependent 


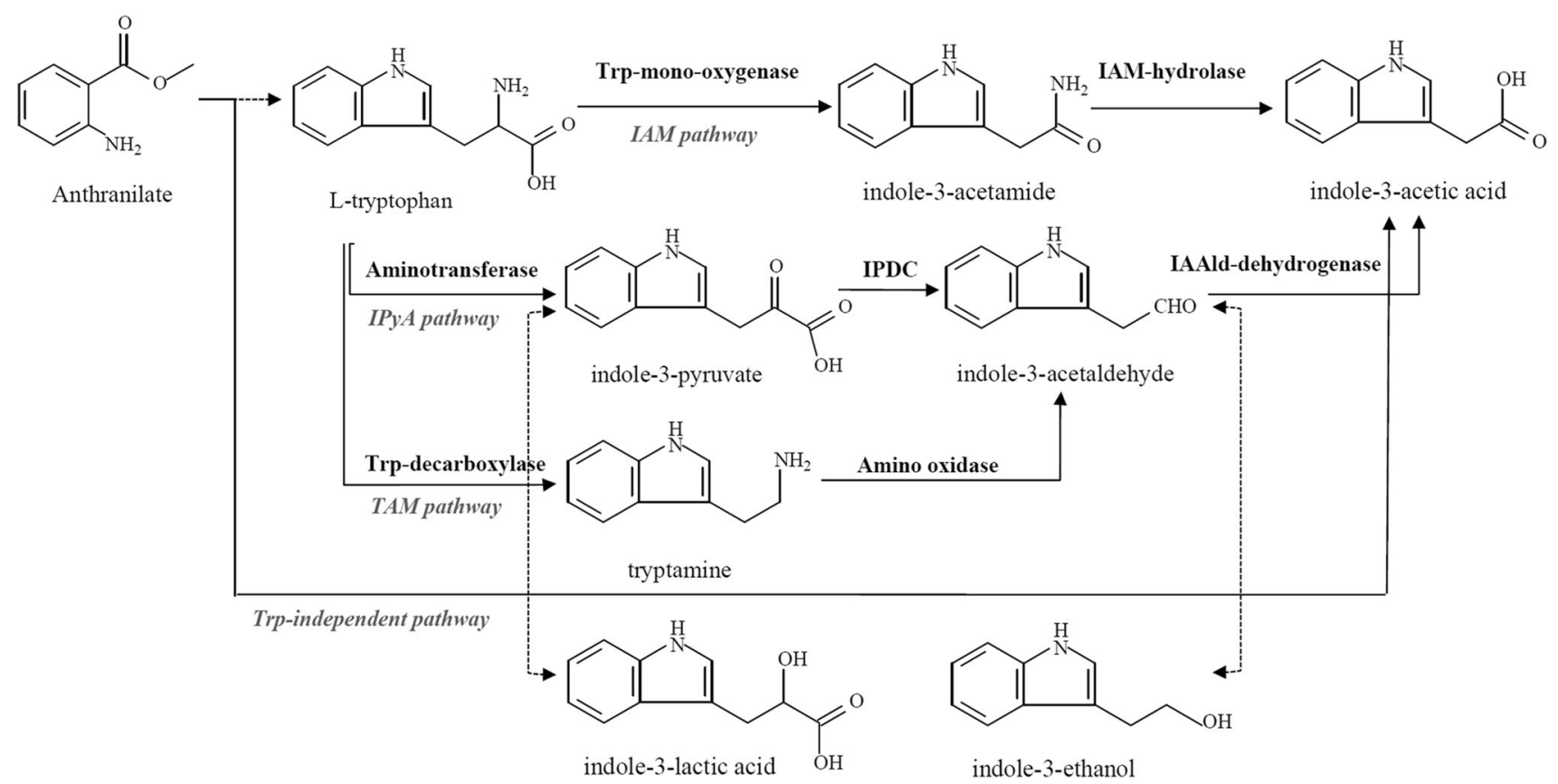

Fig. 2 Hypothetical and characterized pathways to synthesize indole-3-acetic acid (IAA) in Azospirillum sp. Dotted lines represent hypothetical conversion steps to storage products

pathways (via IPyA, IAM, and TAM) and one Trp-independent pathway (Prinsen and others 1993; Carreño-López and others 2000). See Fig. 2 for an overview of the IAA biosynthesis proposed in Azospirillum sp.

Although it has always been suggested that the bacterial IPyA pathway resembles the one present in higher plants (Nonhebel and others 1993), the bacterial and plant IPyA pathways have some differences in the reaction steps downstream from the intermediate IPyA, as demonstrated by recent studies on auxin biosynthesis in plants (Korasick and others 2013). In bacteria, the IPyA pathway starts by converting Trp to IPyA by an aromatic amino acid transferase, followed by decarboxylation by an IPyA decarboxylase (IPDC) to indole-3-acetaldehyde, and concludes with oxidation to IAA by indole-3-acetaldehyde dehydrogenase (Baca and others 1994; Costacurta and others 1994). In this sense, Pedraza and others (2004) detected aromatic aminotransferase (AAT) activity in cell-free crude extracts of four strains of A. brasilense and one of A. lipoferum, and all strains displayed two isoforms with different molecular weights. Ge and Chen (2009) evaluated the expression and functionality of atrC of A. brasilense Yu62 in E. coli and found that this gene encodes for a novel aminotransferase involved in IAA biosynthesis. Recently, Castro-Guerrero and others (2012) identified the his $\mathrm{Cl}$ gene in $\mathrm{A}$. brasilense $\mathrm{Sp} 7$, which encodes aromatic amino acid aminotransferase-1 (AAT1) and they showed that his $\mathrm{Cl}$ gene expression is induced by root exudates and on plants, suggesting that AAT1 plays a role in conversion of Trp into IAA. The IPyA pathway was initially demonstrated in A. brasilense Sp245 by cloning the ipdC gene, which encodes an IPDC (Costacurta and others 1994). The expression of this gene is upregulated by the end product IAA itself, which represented the first case of a bacterial gene specifically regulated by auxin (Vande Broek and others 1999). The ipdC promoter sequence contains an auxin response element (AuxRE), which is similar to the AuxRE found in gene promoters induced by auxin in higher plants (Lambrecht and others 1999). The IPDC enzyme is the key enzyme in the IPyA pathway because it is the rate-limiting step in this pathway and an ipdC knockout mutant is strongly reduced in IAA biosynthesis (Prinsen and others 1993). Certain aspects of the IPyA pathway, such as the characterization and expression regulation of the ipdC gene/region, have also been studied in other A. brasilense species such as strain $\mathrm{Sp} 7$ and SM (Malhotra and Srivastava 2008; Rothballer and others 2005).

In the TAM pathway, Trp is initially converted to TAM, catalyzed by a pyridoxal-phosphate-dependent Trp decarboxylase, followed by conversion to indole-3-acetaldehyde by an amino-oxidase. Although this pathway is present in plants (Conney and Nonhebel 1991) and fungi (Frankenberger and Arshad 1995), it is much less documented in bacteria. This pathway was suggested only for Bacillus cereus (Perley and Stowe 1966) and A. brasilense (Hartmann and others 1983) based on their ability to produce IAA from TAM in chemically defined culture medium. 
Subsequently, Ruckäschel and Klingmüller (1992) detected the intermediates of the pathway in supernatants of A. lipoferum, confirming this route in other species of the genus.

The IAM pathway has been studied mainly in phytopathogenic bacteria (Klee and others 1984). The existence of this pathway in A. brasilense was suggested by Prinsen and others (1993) and Bar and Okon (1993), who determined the presence of IAM in cell-free supernatant. However, no further work was reported for this pathway in Azospirillum.

The Trp-independent pathway has been described through labeled precursor experiments by Prinsen and others (1993), who suggested that conversion of IAA (in the absence of exogenously added Trp) in A. brasilense has a distribution of $0.1,10.0$, and $90.0 \%$ for the IAM, IPyA, and Trp-independent pathway, respectively. This latter route has been questioned as attempts to isolate an enzyme or gene responsible for this activity have failed.

Genomic Analysis of IAA Production by Azospirillum sp.

To date, six full genomes have been sequenced for bacteria belonging to the genus Azospirillum: A. brasilense Sp245 (Wisniewski-Dyé and others 2011), A. brasilense Az39 (Cassán and others unpublished data), A. brasilense CBG497 (Wisniewski-Dyé and others 2012), A. lipoferum 4B (Wisniewski-Dyé and others 2011), Azospirillum sp. B510 (Kaneko and others 2010), and A. amazonense Y2 (Sant'Anna and others 2011). In this section, we aim to unravel putative auxin biosynthesis pathways in Azospirillum strains by identifying involved genes in the genome sequence using a BLAST search (Table 1).

A. brasilense $\mathrm{Sp} 245$ is one of the most studied strains worldwide and is considered as a typical strain for this species, especially with respect to its auxin biosynthesis. It was isolated from surface-sterilized wheat roots from $\mathrm{Pa}$ raná state in south Brazil (Baldani and others 1986) and was one of the most promising strains for wheat inoculation in Brazil during the $1980 \mathrm{~s}$. IAA production by A. brasilense Sp245 has been studied extensively, with the IPyA pathway the main route for IAA biosynthesis. All genes (aromatic amino transferase, ipdC, and aldehyde dehydrogenase) involved in this pathway are present in the genome sequence of $A$. brasilense Sp245. Additionally, two putative nitrilase genes (NIT1 and NIT2) could be identified in Sp245 by p-BLAST, with up to $75 \%$ homology to those studied in Arabidopsis thaliana (Wisniewski-Dyé and others 2012). The putative nitrilase enzymes could catalyze the conversion of IAN to IAA via the IAN pathway. However, based on the substrate preference of NIT1 and NIT2 of A. thaliana pointing to a role in cyanide detoxification and

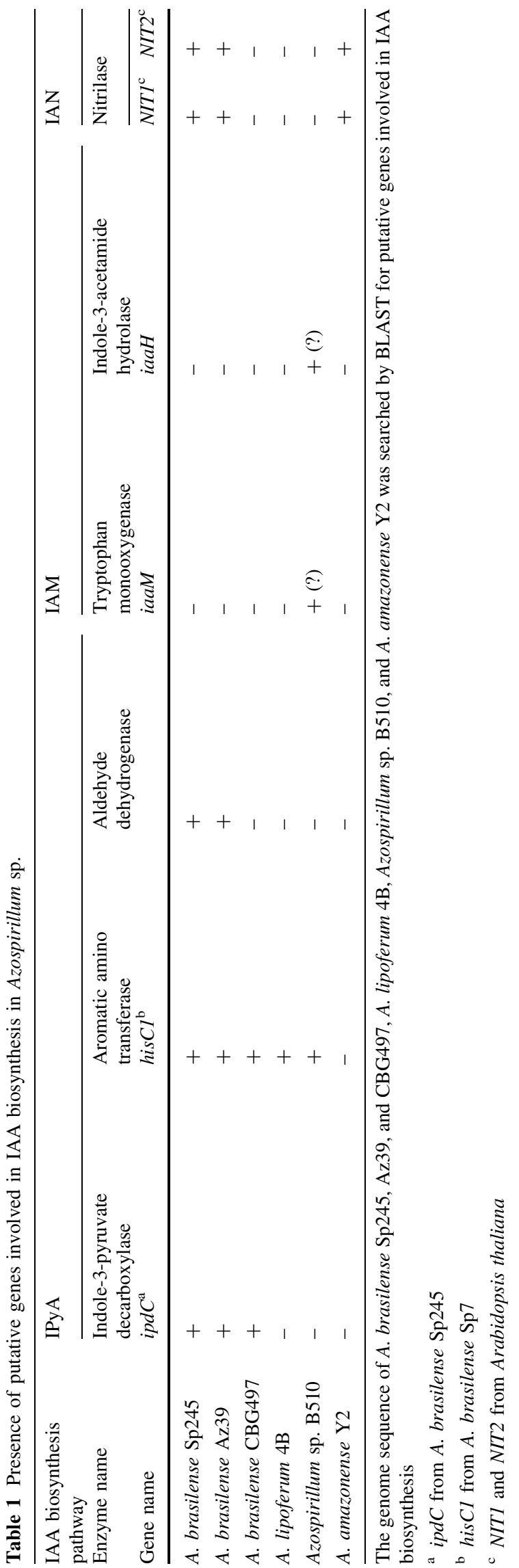


glucosinolate catabolism, their role in bacterial auxin production can be questioned (Piotrowski 2008).

A. brasilense Az39 has been the most used strain for inoculant formulation in Argentina for more than 40 years. The strain was isolated from surface-sterilized seedlings of wheat plants in the central region of Argentina and selected based on its ability to increase growth and yield of different crops under agronomic conditions (Díaz-Zorita and Fernández Canigia 2009). At the full-genome sequence level, strains Sp245 and Az39 are very similar. Therefore, it is not surprising that all genes encoding for the IPyA pathway can be found in the Az39 genome sequence and are highly similar to the corresponding genes of strain Sp245 (similarity ranging from 97 to $99 \%$ ). A gene similar (99\% similarity) to the nitrilase genes of strain Sp245 could also be detected in the genome of Az39.

A. brasilense CBG497 was isolated from maize grown on an alkaline soil in the northeast of Mexico and was able to stimulate maize biomass yield under greenhouse conditions (García-Olivares and others 2007). As for strains Sp245 and Az39, IAA production by $A$. brasilense CBG497 seems to occur via the IPyA pathway. The gene encoding the aromatic amino transferase and ipdC involved in this pathway were found in the genome sequence (Wisniewski-Dyé and others 2012). There is no evidence of the presence of nitrilase genes in this strain (WisniewskiDyé and others 2012).

A. lipoferum 4B was isolated from the rice rhizosphere (Bally and others 1983) and was successfully used as an inoculant to increase rice yield under field conditions (Charyulu and others 1985). No evidence has been found for the existence of $i p d \mathrm{C}$ or aldehyde dehydrogenase genes in the genome sequence of A. lipoferum 4B. Only a putative aromatic amino transferase sequence with homology to AAT1 from A. brasilense Sp7 was identified (WisniewskiDyé and others 2012), although it is worth mentioning that these enzymes have a broad substrate spectrum.

Azospirillum sp. B510 is an endophytic bacterium isolated from surface-sterilized stems of rice plants in Kashimadai, Japan (Elbeltagy and others 2001). This strain was not assigned a species name, but based on high homology with the genome sequence of A. lipoferum 4B, it can be regarded as a A. lipoferum strain. Genome sequence analysis revealed a putative aromatic amino transferase with homology to AAT1 from A. brasilense Sp7 (Wisniewski-Dyé and others 2012). Two candidate genes were proposed to be involved in the IAM pathway (Kaneko and others 2010), although we question their role in IAA biosynthesis due to low similarity (especially for the putative iaaM gene) with known iaaM and $i a a H$ genes.

A. amazonense was isolated from forage grasses in the Amazon region, but further studies revealed its broad ecological distribution in association with gramineous plants (Magalhães and others 1983). Although A. amazonense is able to synthesize IAA (Rodrigues and others 2008), very little is known about the molecular mechanisms involved (Sant'Anna and others 2011). Genome sequence analysis could not reveal the presence of genes involved in the IPyA or IAM pathway (ipdC, iaaM, or $i a a H)$, but did reveal a gene encoding a protein with about $70 \%$ similarity to nitrilases of A. thaliana (Vorwerk and others 2001).

\section{Environmental Factors that Regulate IAA Biosynthesis}

The environmental factors that affect IAA biosynthesis in Azospirillum sp. are diverse and extensive. Therefore, we discuss only those related to environmental stress and plant signaling (Spaepen and others 2007). The first group of factors includes acidification, osmotic and matrix stresses, and carbon source limitation. The second group includes chemical effectors and molecules produced by plants during stress conditions. IAA production is increased under carbon limitation, during growth rate reduction, and acidic pH (Ona and others 2003, 2005). Interestingly, carbon limitation and growth rate reduction are related to the physiological state of bacteria when entering the stationary growth phase. IAA is produced during all stages of culture growth but increases significantly in the stationary phase (Malhotra and Srivastava 2009). Acidic pH increases ipdC gene expression in $A$. brasilense, followed by a subsequent increase in IAA production (Vande Broek and others 2005). Using an ipdC-gusA translation fusion, Vande Broek and others (2005) demonstrated that expression of the ipdC gene is induced mainly during the stationary growth phase, coinciding with IAA accumulation in the culture medium. IAA production is increased by osmotic stress, abscisic acid (ABA), phytopathogenic fungal effectors, or some L-amino acids when added to exponential cultures of A. brasilense strains Sp245 and Az39 (Cassán and others unpublished data). In contrast, oxidative stress, salinity, methyl jasmonate (MeJA), phytopathogenic bacterial effectors, or some L-amino acids decreased IAA accumulation under similar experimental conditions. In other research, the Pseudomonas fluorescens F113 secondary metabolite 2,4-diacetylphloroglucinol (DAPG) was proposed as a new environmental signal that induces expression of $A$. brasilense Sp245 genes involved in plant growth promotion (Combes-Meynet and others 2011). The authors showed that both expression of ipdC and IAA production are significantly increased by the addition of DAPG in culture medium.

The results summarized in this section suggest that Azospirillum sp. strains have the capacity to perceive physiological signals produced (and perceived) by plants or microorganisms under environmental stress conditions and 
modify their metabolism to coordinate a unique response together with the plant.

Physiological Effects of Auxins on Azospirillum sp.

A microarray analysis to study the overall effects of IAA on the transcriptome of $A$. brasilense Sp245 wild-type and ipdC knockout mutant, both cultured in the absence and presence of exogenously added IAA, was reported by Van Puyvelde and others (2011). Based on the multitude of changes observed by comparing the different transcriptomes, the authors concluded that IAA is a signalling molecule in A. brasilense allowing the bacterium to adapt itself in the presence of IAA to the plant rhizosphere by changing its arsenal of transport proteins and cell surface proteins.

Physiological and Ecological Effects of Auxins Produced by Azospirillum sp.

The primary source of exogenous auxins for plants is the rhizosphere (Patten and Glick 1996). The plant response to exogenous IAA can vary from beneficial to deleterious depending on the concentration perceived by plant tissues and tissue sensitivity. In the case of a beneficial response, the increased hormone content of the rhizosphere due to microbial activity supplements temporarily suboptimal levels in plants and partially modifies the plant cell metabolism with consequent growth promotion (Frankenberger and Arshad 1995). The best reported model of plant growth promotion induced by microbial activity in the rhizosphere is Azospirillum sp. for which auxin production has been described to be the main factor responsible for plant growth promotion, based on (1) nodule ontogeny in Rhizobiumlegume symbiosis, (2) development of the root system in gramineous plants, and (3) regulation of other rhizobacteria.

\section{Effects of Auxins Produced by Azospirillum sp. on Rhizobium-Legume Symbiosis}

Most members of the Rhizobiales order induce nodule formation on legume roots and these structures provide the plant with fixed atmospheric nitrogen (Bergersen 1971). For over 70 years, since Thiman (1936) proposed that auxins play an important role in the ontogeny (formation and development) of the nodule in Rhizobium-legume symbiosis, many studies have indicated that changes in the concentration of this phytohormone or its balance with CK are a prerequisite for nodule organogenesis (Mathesius and others 1997). Therefore, co-inoculation with Rhizobium and auxin-producing bacteria can influence the symbiotic outcome by altering the phytohormonal homeostasis.

Inoculation of common bean seedlings with A. brasilense resulted in increased production of plant root flavonoids and enhanced capacity to induce nod gene expression in Rhizobium as compared with noninoculated seedlings (Burdman and others 1996). In many rhizobia the expression of nod genes and the synthesis of Nod factors, as well as IAA, are triggered by flavonoids produced by the plant (see Cooper 2007 for a review). The positive effects of $A$. brasilense $\mathrm{Cd}$ on legume growth, nodule organogenesis, flavonoids, and lipochitooligosaccharide production were assessed in a Rhizobium-common bean hydroponic growth system by Dardanelli and others (2008). Other reports have shown the beneficial effect of co-inoculation with Rhizobium and Azospirillum in legumes on biological nitrogen fixation, not only at the molecular level or root and nodule morphology, but also for nodule functionality (increase in nitrogenase activity in symbiosomes) (Yahalom and others 1990). Coinoculation of Sinorhizobium meliloti (inefficient IAA producer) with $A$. brasilense (efficient IAA producer) on alfalfa seeds significantly increased the number of root nodules in the primary root. The increase was correlated with the inoculum size. This response could be mimicked by the addition of exogenous IAA (Schmidt and others 1988). Direct evidence of the role of IAA-promoting effects in coinoculation studies of $A$. brasilense and $R$. etli on common bean was also provided by Remans and others (2008a, b) with the use of the ipdC knockout mutant of $A$. brasilense.

\section{Effects of Auxins Produced by Azospirillum sp. on Gramineous Plants}

Root growth is perhaps the most remarkably changed parameter in the interaction of PGPR and grasses. The rapid seedling establishment in substrate due to root growth promotion must be considered a clear advantage for plants because it can improve the absorption of water and nutrients. Simultaneously, Tien and others (1979) and Hubbell and others (1979) proved that the exogenous application of IAA, $\mathrm{GA}_{3}$, and kinetin (a $\mathrm{CK}$ ) in pearl millet and sorghum produced changes in root morphology similar to those found in seedlings inoculated with A. brasilense. Later it was shown that inoculation of Beta vulgaris sp. with A. brasilense increased the number of lateral roots compared to control plants. This effect was correlated with the high levels of bacterial IAA in pure liquid culture and could be mimicked by exogenous application of similar IAA concentrations (Kolb and Martin 1985). Also, in wheat plants, inoculation with $A$. brasilense simulates the effect of exogenous IAA and $\mathrm{GA}_{3}$ treatment in regard to the growth pattern of stems and roots (Kucey 1988). Furthermore, the exogenous addition of IAA and nitrate to wheat plants could (partly to fully) be replaced by the inoculation with A. brasilense (Zimmer and others 1988). The levels of free IAA and IBA in seedlings of maize (Zea mays L.) inoculated with $A$. brasilense $\mathrm{Cd}$ were higher than 
in noninoculated roots as measured by gas liquid chromatography (GLC) and gas chromatography-mass spectrometry (GC-MS) (Falik and others 1989). Further evidence of the role of bacterial auxin production was provided by inoculation studies with strains altered in IAA biosynthesis: inoculation with a wild-type IAA-producing strain of A. brasilense increased the number and length of lateral roots of wheat. In contrast, inoculation with a bacterial mutant with lower IAA production did not modify the root morphology (Barbieri and others 1988). Bothe and others (1992) demonstrated that inoculation of wheat plants with A. brasilense significantly increased the formation of lateral roots and slightly increased the dry weight of roots and root hair formation, whereas exogenous application of IAA significantly increased root dry weight but had no effect on the formation of lateral roots. The role of IAA in the phytostimulatory effect upon Azospirillum sp. inoculation was demonstrated by comparing the plant-growth-promoting effects of wild-type, auxin-impaired (ipdC knockout) mutant, and strains altered in auxin production. Inoculation with the wild-type strain resulted in a decrease in root length but an increase in root hair length and density, whereas inoculation with the ipdC mutant did not cause these morphological changes, providing direct evidence for the role of IAA production. In addition, altered IAA production caused by exchanging the native promoter of the ipdC gene with a constitutive or plant-inducible promoter further pronounced the effect of inoculation (Dobbelaere and others 1999; Spaepen and others 2008).

\section{Effects of Auxins Produced by Azospirillum sp. on Rhizosphere Microbiota}

In regard to the effects of Azospirillum sp. on the rhizosphere microflora of inoculated plants, Baudoin and others (2010) evaluated the phytostimulatory effects of $A$. brasilense genetically modified at the level of IAA biosynthesis in rhizosphere microbiota. This study shows that changing the regulation of the ipdC in $A$. brasilense can have a significant effect on root-colonizing microbiota. This ecological impact depends not only on the promoter regulating the ipdC in genetically modified Azospirillum inoculants (that is, constitutive promoter versus root exudate-responsive promoter), but also on the genetic construct itself (that is, presence or absence of a plasmid vector) and the microbial community (that is, bacteria versus fungi).

\section{Gibberellins}

Gibberellins (GAs) are a large group of tetracyclic diterpene acids that regulate diverse processes in plants, including germination, stem elongation, flowering, and fruiting (Davies 1995). To date, more than 130 gibberellin molecules produced by plants, fungi, and bacteria have been identified (Hedden and Phillips 2000).

\section{Molecular Structure and Biological Activity}

There are two main classes of gibberellins, the free form and conjugated form. Free gibberellins are divided into two subgroups, those that possess the full complement of carbon atoms or $\mathrm{C}_{20}$-GAs and those in which the $\mathrm{C}_{20}$ is lost or $\mathrm{C}_{19}$-GAs (Fig. 3). All gibberellins are carboxylated at $\mathrm{C}_{7}$, with the exception of $\mathrm{GA}_{12}$-aldehyde, and possess one $\left(\mathrm{G}_{4}\right)$, two $\left(\mathrm{GA}_{1}\right)$, three $\left(\mathrm{GA}_{8}\right)$, or four $\left(\mathrm{GA}_{32}\right)$ hydroxyl functions. The position of the hydroxylation $(\mathrm{OH})$ is very important because it determines the biological activity of the molecule. Hydroxylation of $\mathrm{C}_{3}$ and $\mathrm{C}_{13}$ in their $\mathrm{B}$ and $\alpha$ position, respectively, leads to the activation of the molecule, whereas the hydroxylation of $\mathrm{C}_{2}$ in position $B$ has a strong negative effect on activity (Pearce and others 1994). In addition to the free forms, conjugated forms have been identified in plants (Fig. 4). These include glycoside ethers (GA-G), in which a sugar molecule is attached to the structure of the GA by a hydroxyl group, and glycoside esters (GA-GE), in which a sugar residue is bound to the hormone through a carboxyl group on $\mathrm{C}_{7}$ (Sembder and others 1980). The biochemical and physiological aspects of the GA conjugates have been discussed by Rood and Pharis (1987), who suggest that the main feature of these compounds is the lack of biological activity and the potential reversibility to the active forms by hydrolytic enzyme activity.

Biosynthesis and Metabolism of Gibberellins by Azospirillum sp. in Culture Medium

Bottini and others (1989) were the first to confirm the ability of Azospirillum sp. to produce gibberellins in chemically defined medium. Using GC-MS analysis, they reported the production of $\mathrm{GA}_{1}$ and $\mathrm{GA}_{3}$ in a nitrogen-free medium culture of $A$. lipoferum Op33. Similar results were reported in A. brasilense Cd (Janzen and others 1992) and in A. lipoferum AZm5 and A. brasilense VS9 (EsquivelCote and others 2010). In addition, the production of inactive precursors $\mathrm{GA}_{19}$ and $\mathrm{GA}_{9}$ in chemically defined medium of A. lipoferum Op33 was reported (Piccoli and Bottini 1996), pointing to the existence of different biosynthetic pathways. The first pathway presumably includes an early $13 \alpha$-hydroxylation of a common precursor followed by its metabolism to $\mathrm{GA}_{19}$ and subsequently to $\mathrm{GA}_{20}$, and finally the 3B-hydroxylation to $\mathrm{GA}_{1}$, whereas the second pathway starts with the metabolism of the common 
Fig. 3 Chemical structures of gibberellins. a Gibberellic $\mathrm{C}_{20}$ and $\mathrm{C}_{19}$ skeletons.

b Biologically inactive gibberellins $\mathrm{GA}_{12}$-aldehyde (precursor) and $\mathrm{GA}_{8}$ (catabolite). c Biologically inactive glucosyl conjugates of $\mathrm{GA}_{1}$. d Biologically active $\mathrm{GA}_{3}$ and $\mathrm{GA}_{1}$
A

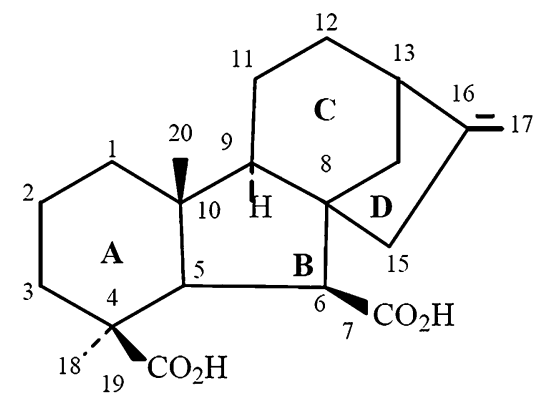

GA-C 20 skeleton

B

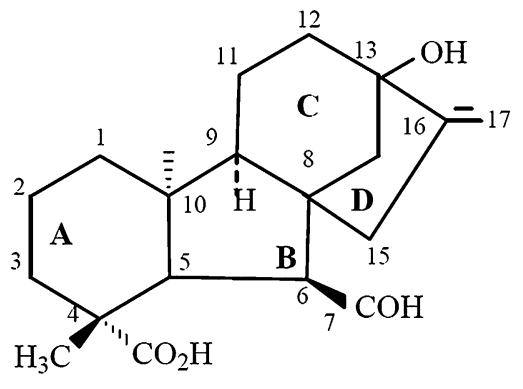

GA $_{12}$-aldehyde

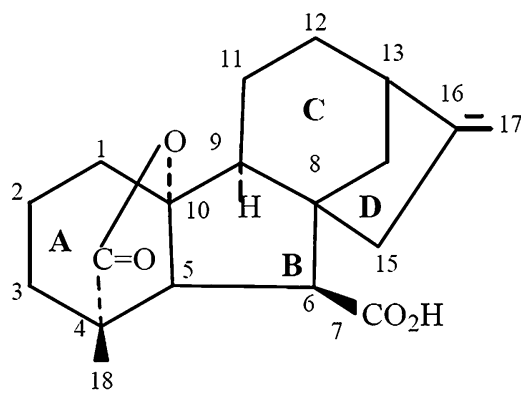

GA-C 19 skeleton

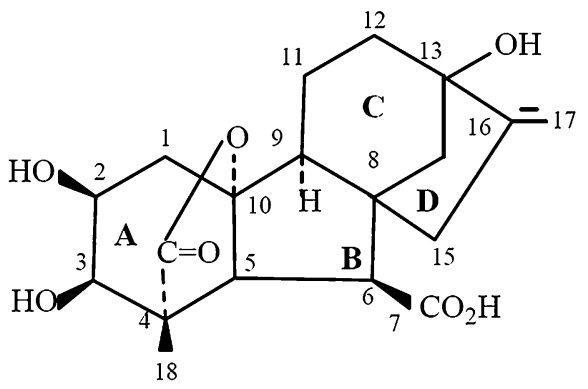

$\mathbf{G A}_{8}$

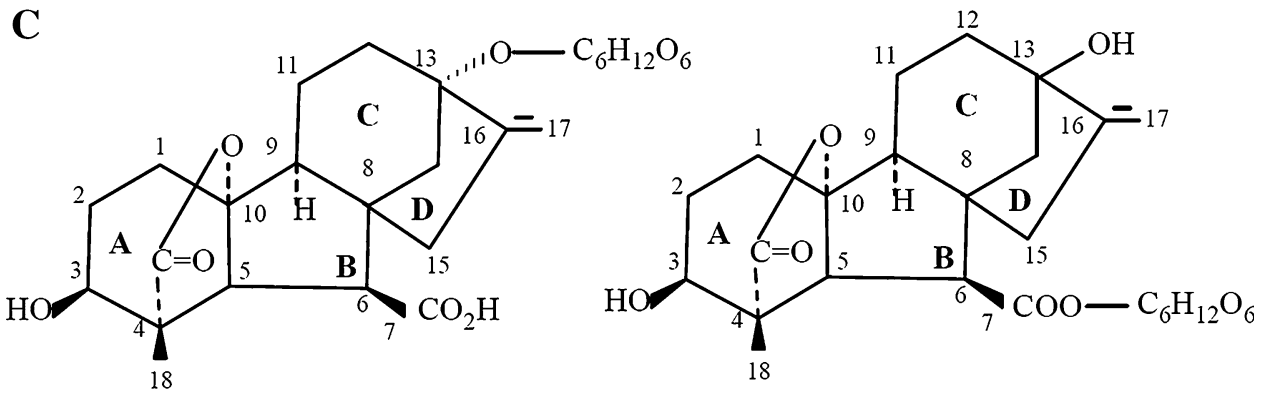

$\mathrm{GA}_{1}$-13-O-glucoside

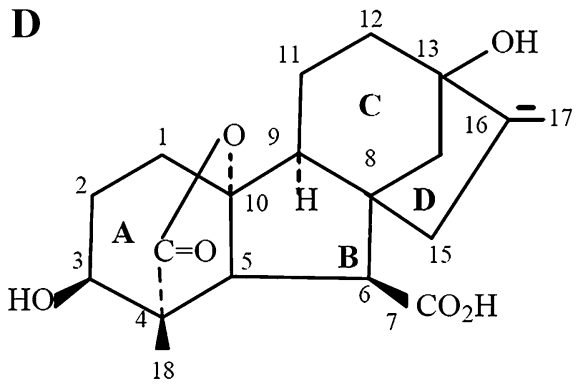

$\mathbf{G A}_{1}$

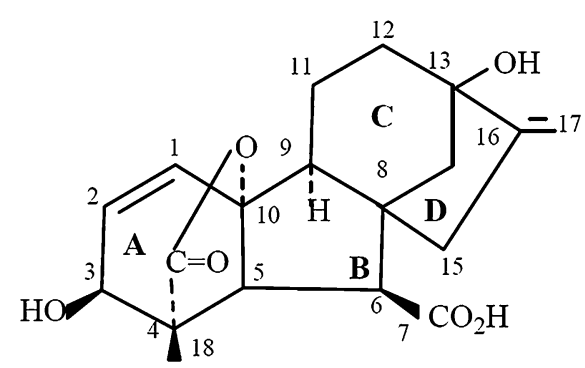

$\mathbf{G A}_{3}$ precursor to $\mathrm{GA}_{9}$ and the simultaneous $3 \beta$-hydroxylation to $\mathrm{GA}_{4}$, and finally $13 \alpha$-hydroxylation to $\mathrm{GA}_{3}$. These different pathways were confirmed in later reports for A. lipoferum Op33 by use of minimal medium supplemented with deuterium-labeled precursors $\mathrm{GA}_{20}$ and $\mathrm{GA}_{9}$ and the identification of deuterated $\mathrm{GA}_{1}$ and $\mathrm{GA}_{3}$ by GC-MS
(Piccoli and Bottini 1994a, 1996). In addition, A. lipoferum Op33 produces $\mathrm{GA}_{20}$ and $\mathrm{GA}_{5}$ in liquid culture medium (Piccoli and Bottini 1996), suggesting the existence of a second $13 \alpha$-hydroxylation pathway metabolizing $\mathrm{GA}_{20}$ to $\mathrm{GA}_{5}$ and the final 3ß-hydroxylation to $\mathrm{GA}_{3}$. However, this pathway has not been confirmed. Using labeled precursors, 


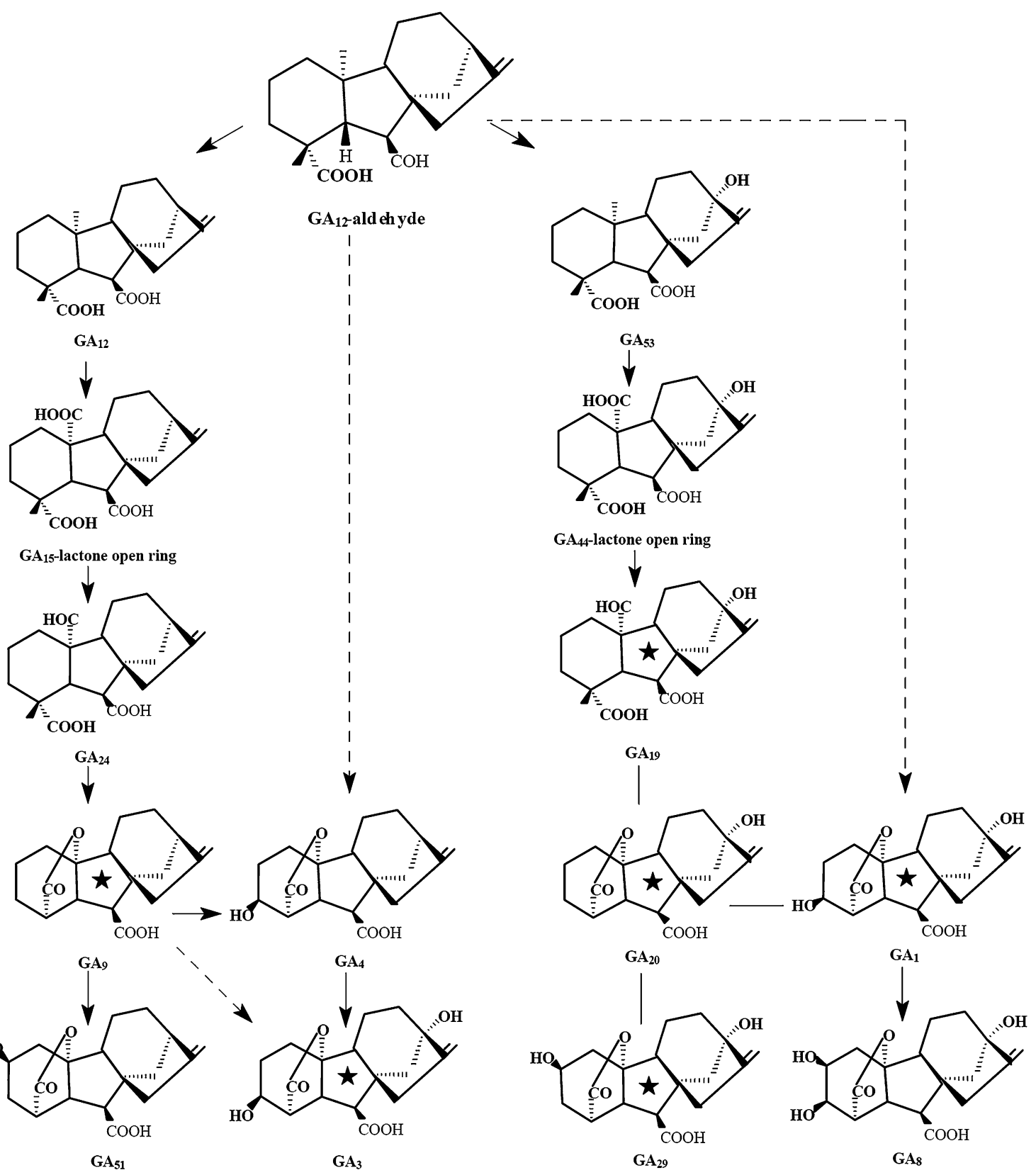

Non-13-hydroxylative pathway

Early 13-hydroxylative pathway

Fig. 4 The putative GA biosynthesis pathways in Azospirillum sp. according to the gibberellin molecules identified in the bacteria and the model proposed by Kobayashi and others (1989) in rice (Oryza

similar experiments were performed by Piccoli and others (1997) to evaluate the A. lipoferum USDA5b capacity to hydrolyze the gibberellin conjugates with glucose $\mathrm{GA}_{20^{-}}$ glycosyl ester and $\mathrm{GA}_{20}-13-O$-glucoside and metabolize it to the biologically active molecule $\mathrm{GA}_{1}$. Production, metabolism, and conjugate hydrolysis of GAs by Azospirillum sp. have been comprehensively summarized by Bottini and others (2004). sativa L.). Dotted arrows represent reactions in bacteria, full arrows represent reactions in plants, and full lines represent reactions in both bacteria and plants

Biosynthesis and Metabolism of Gibberellins by Azospirillum sp. in Planta

The effect of GA-producing bacteria on plants was studied using mostly plant dwarf mutants according to the methods of Murakami (1968) and Kobayashi and others (1989). Seedlings of dwarf cultivars of maize (Phinney and Spray 1988) and rice (Murakami 1972) were inoculated with 
A. brasilense or A. lipoferum in the presence or absence of plant growth retardants (gibberellin biosynthesis inhibitors) (Rademacher 2000) with the aim of evaluating the reversion of plant dwarfism due to the bacterial biosynthesis and/or metabolism of gibberellins. The first evidence on the capacity of Azospirillum sp. to produce active gibberellins in planta was reported by Lucangelli and Bottini (1997). They reported the reversal of dwarfism in dwarf mutants of maize and rice by inoculation with $A$. lipoferum USA5b and $A$. brasilense Cd. Cassán and others (2001c) presented evidence about the endophytic capacity of Azospirillum sp. to metabolize inactive precursors to active gibberellins by the reversion of rice dwarfism and identification of $\left[17,17-{ }^{2} \mathrm{H}_{2}\right]-\mathrm{GA}_{1}$ by GC-MS in root and shoot tissues pretreated with $\left[17,17-{ }^{2} \mathrm{H}_{2}\right]-\mathrm{GA}_{20}$. These results confirmed the capacity of Azospirillum sp. to produce $\mathrm{GA}_{1}$ from $\mathrm{GA}_{20}$ through the 3ß-hydroxylation pathway. In similar experimental conditions, Cassán and others (2001a) demonstrated the ability of Azospirillum sp. to hydroxylate $\left[17,17-{ }^{2} \mathrm{H}_{2}\right]-$ $\mathrm{GA}_{9}$ to $\left[17,17-{ }^{2} \mathrm{H}_{2}\right]-\mathrm{GA}_{3}$, confirming the existence of a second biosynthetic pathway. Inoculation of rice dwarf mutants pretreated with the early precursor $\left[17,17-{ }^{2} \mathrm{H}_{2}\right]-$ $\mathrm{GA}_{12}$ also reversed dwarfism. This result can be explained by the ability of bacteria to metabolize ${ }^{2} \mathrm{H}_{2}-\mathrm{GA}_{12}$ to the biologically active ${ }^{2} \mathrm{H}_{2}-\mathrm{GA}_{1}$ or ${ }^{2} \mathrm{H}_{2}-\mathrm{GA}_{3}$. In regard to metabolism of conjugates, it was observed that Azospirillum sp. can reverse genetic dwarfism in inoculated rice seedlings treated with $\left[17,17-{ }^{2} \mathrm{H}_{2}\right]-\mathrm{GA}_{20}$-glycosyl ester or $\left[17,17-{ }^{2} \mathrm{H}_{2}\right]-\mathrm{GA}_{20}$-glycosyl ether. In these seedlings, phenotypic complementation was observed and the phenotype correlated with the ability of the bacteria (1) to hydrolyze $\mathrm{GA}_{20}$-glucosyl ester or $\mathrm{GA}_{20}$-glucosyl ether to $\mathrm{GA}_{20}$ and (2) to metabolize this precursor to the active $\mathrm{GA}_{1}$ by $33-$ hydroxylase enzymes (Cassán and others 2001b). See Fig. 4 for an overview of the gibberellin biosynthetic pathways proposed in Azospirillum sp.

\section{Environmental Factors that Modify GA Production by Azospirillum sp.}

GA biosynthesis in bacteria increases rapidly at the beginning of the stationary growth phase, suggesting that reduced nutrients in the culture medium may trigger bacterial GA production, as occurs for auxin production (Omay and others 1993). High concentrations of $\mathrm{NH}_{4} \mathrm{Cl}$ in the culture medium decreased the amount of $\mathrm{GA}_{3}$ released (Piccoli and Bottini 1994b), which is comparable to fungi for which gibberellin synthesis initiates when $\mathrm{N}$ availability decreases (Rademacher 2000). Other environmental factors are the availability of $\mathrm{O}_{2}$ and the osmotic potential (Piccoli and others 1999), which can influence the quantity of gibberellins produced by Azospirillum sp. The quantity of $\mathrm{GA}_{3}$ was severely reduced by restricted gas exchange or the addition of PEG as an osmotic agent $\left(\Psi_{\mathrm{w}}=\right.$ $-1.21 \mathrm{MPa})$ in culture medium. This reaction has been considered a compensatory mechanism in the bacterium's ability to produce $\mathrm{GA}_{3}$ under drought conditions (Piccoli and others 1999).

Physiological Role of GAs Produced by Azospirillum sp.

There is an extensive list of publications related to the effects of Azospirillum sp. inoculation on growth during the early-development stages in plants, as presented by Bashan and de Bashan (2010). The common changes in plant phenotype upon inoculation can be summarized as follows: (1) increase in root growth, (2) increase in germination rates, and (3) rapid growth of seedlings compared to noninoculated controls. The increase in root growth can be attributed to mainly bacterial auxin production, whereas the other effects can be attributed, at least partially, to GA production.

\section{Cytokinins}

Cytokinins are a group of natural compounds that regulate cell division and differentiation processes in meristematic tissues of higher plants. There are two structural groups of cytokinins: the adenine-type cytokinin group represented by natural and synthetic compounds such as kinetin $(\mathrm{K})$, zeatin (Z), or 6-benzylaminopurine (6-BAP), and the phenylurea-type cytokinin group represented by the synthetic molecules diphenylurea and thidiazuron (TDZ) (Fig. 5). Chemically, adenine-type cytokinins are purines, derived mostly from adenine and modified by substitutions on the $\mathrm{N}^{6}$, which also include their respective ribotides, ribosides, and glycosides. These plant hormones have been associated with many physiological and cellular processes, including senescence delay by chlorophyll accumulation and organ formation in a wide range of tissues, root development, root hair formation, root elongation, stem initiation, and leaf expansion (Sakakibara 2006). By definition, these compounds (combined with an optimal auxin concentration) induce cell division in plants. The first synthetic cytokinin molecule was discovered by Miller and others (1955) and was named kinetin (K). In 1963, Letham (1963) identified a naturally occurring compound called zeatin (Z) and since then more than 50 molecules and their metabolites have been classified as CKs. The biological activity for all CK-like compounds is not uniform and normally depends on several structural aspects such as a purine ring in the molecule, substitution of $\mathrm{N}^{6}$ with a simple ribosyl chain isopurine-derived unit, and substitution on positions 2 and 9 of the ring for $\mathrm{H}, \mathrm{CH}_{3}-\mathrm{S}$, or an 
A<smiles>C/C(=C\CNc1ncnc2[nH]cnc12)CO</smiles>

Zeatin<smiles>c1coc(CNc2ncnc3[nH]cnc23)c1</smiles>

Kinetin<smiles>CC(C)=CC(=O)Nc1ncnc2[nH]cnc12</smiles>

Isopentenyladenine<smiles>c1ccc(CNc2ncnc3[nH]cnc23)cc1</smiles>

6-benzylaminopurine

Fig. 5 Structure of cytokinins identified and reported in Azospirillum sp. a and synthetic molecules $\mathbf{b}$ with cytokinin activity on plant tissues

unsaturated side chain (optimal five carbons). The natural and synthetic adenine-type cytokinin molecules with confirmed biological activity on plant tissues are zeatin, isopentenyl adenine, kinetin, and 6-benzylaminopurine, and all of them have a double alkyl bridge at position $\mathrm{N}^{6}$.

Cytokinin Production by Azospirillum sp.

At least $90 \%$ of bacteria isolated from the rhizosphere of agriculturally important crops are estimated to be able to produce CK-like compounds in culture medium (Barea and others 1976). Tien and others (1979) were the first to demonstrate the ability of $A$. brasilense to produce CK-like molecules using different types of chromatography (HPLC and TLC) and an inoculation bioassay in pearl millet. However, the partially purified compounds were not fully characterized. Similar results were obtained by Muralidhara and Rai (1986) in A. lipoferum. In addition, inoculation caused significant changes in root morphology by increasing the number of lateral roots and the root hair density like those obtained by application of exogenous CKs (Tien and others 1979). A modified chromatography extraction method and application of a radio-immunoassay demonstrated that A. brasilense produces isopentenyl adenine, isopentenyl adenine riboside, and zeatin in chemically defined medium (Horemans and others 1986). The lack of information about CK biosynthesis in Azospirillum sp. is partially due to the complexity of chemical analysis of these

hormones. The most significant work on CK production by Azospirillum sp. was published by Strzelczyk and others (1994); they used culture medium supplemented with different $\mathrm{C}$ sources. The production of isopentenyl adenine (iP), isopentenyl adenine riboside (iPr), trans-zeatin riboside (trans-Z), and zeatin (Z) by three strains of Azospirillum sp. isolated from the ectomycorrhizal fungi Rhizopogon vinicolor, Laccaria laccata, and Hebeloma crustuliniforme sporocarpus using a soybean callus bioassay was reported by Strzelczyk and others (1994), who used culture medium supplemented with different $C$ sources. However, only the production of iP could be confirmed by GC, which puts into question the production of trans-Z and Z. Recently, the production of trans- $\mathrm{Z}$ by A. lipoferum $\mathrm{AZm} 5$ growing in defined $\mathrm{NFb}$ medium supplemented with $\mathrm{NH}_{4} \mathrm{Cl}$ was reported (Esquivel-Cote and others 2010). An interesting case of synergism was described for a mixed culture of A. brasilense and Arthrobacter giacomelloi which had a higher CK content than that found in the individual cultures of each microorganism (Cacciari and others 1989).

\section{Ethylene}

Ethylene (Et) is an important hormone in plant growth and development (Burg 1962). Because of its gaseous state under physiological conditions, for a long time it was not considered a phytohormone, but various studies showed that its synthesis and action are critical for certain physiological processes. Although there are many publications related to the synthesis of this hormone in higher plants, few studies have been published on microbial biosynthesis of ethylene (Arshad and Frankenberger 1993). Et is a simple and symmetrical molecule composed of two carbon atoms (joined by a double bond) and four $\mathrm{H}$ atoms. Et is soluble in water and can exert its physiological effects at very low concentrations in plant tissues (almost $0.1 \mathrm{ppm}$ ). In higher plants, all tissues have the capacity to synthesize this hormone, but in general Et concentration is associated with the growth state and developmental phase of the plant, with a higher concentration in those tissues involved in active cell division, which are under stressful conditions or in a senescence stage (Burg and Burg 1968).

Biosynthesis and Metabolism of Ethylene by Azospirillum sp.

There is little published information on Et production by PGPR and its effect on plant growth. The ability of the free-living bacteria Azotobacter sp. and Bacillus sp. to produce Et in chemically defined medium was assessed in the early days (Primrose and Dilworth 1976). Later it was shown that Azospirillum sp. produces Et in media with 
malate, succinate, or pyruvate as a carbon source, reaching a maximal production of $0.17 \mu \mathrm{mol} \mathrm{g}{ }^{-1}$ dry weight when L-methionine is added (Strzelczyk and others 1994).

Not only bacterial production of Et can modify plant growth and hormonal "status"; other hormones (for example, IAA) or bacterial enzymes (for example, ACC deaminase) can alter the level of Et in colonized plants. Tomato seedlings inoculated with the auxin-producing A. brasilense strain FT326 showed a positive correlation between IAA concentration, number and length of roots, and plant Et production (up to ten times higher than the controls due to the increase in ACC synthase activity) (Krumpholz and others 2006). This indicates that the plant Et increase is at least partly due to cross-talk between the bacterium-produced IAA and the plant Et biosynthesis, as previously proposed by Rahman and others (2002). The ability of some bacteria to promote plant growth can be correlated to the expression of the bacterial ACC deaminase enzyme (Glick and others 1995). This enzyme can cleave the Et precursor ACC to ammonia and $\alpha$-ketobutyrate, preventing Et accumulation and its negative effects on plant development. Expression of the ACC deaminase gene acdS from Enterobacter cloacae in A. brasilense resulted in significant improvement in growth of inoculated plants, even better than the results obtained by inoculation with the Azospirillum wild-type strain (Holguín and Glick 2001). The ACC deaminase gene acdS was detected in some Azospirillum strains and several $\mathrm{acdS1}^{+}$strains displayed ACC deaminase activity in vitro (Blaha and others 2006). Recently, it was demonstrated that A. lipoferum AZm5 expressing ACC deaminase activity improves the growth of tomato seedlings (Esquivel-Cote and others 2010).

\section{Abscisic Acid}

Abscisic acid (ABA) is the plant hormone that is related mainly to homeostatic regulation under abiotic stress conditions (Nambara and Marion-Poll 2005). This hormone confers to higher plants the ability to adapt to stress through a variety of physiological and molecular processes, including osmotic adjustment, stomatal closure, stressrelated protein biosynthesis, and gene expression regulation (Davies 1995). From a physiological point of view, ABA supports water economy in plants due to its regulatory effect on stomata and could be considered the true plant signal under salt and drought stress conditions (Zhu 2002).

Abscisic Acid Production by Azospirillum sp.

ABA can be produced ubiquitously by higher plants, algae, fungi, and bacteria (Zeevaart 1999). However, there are only a few reports on ABA production by Azospirillum sp. in chemically defined culture medium and in inoculated plants. Kolb and Martin (1985) were the first to report on ABA production by A. brasilense Ft326 in defined culture medium. However, identification of production was achieved by radio-immunoassay, an insensitive technique compared to mass spectrometry, which is more commonly used today. A. brasilense Az39 and Cd have the capacity to produce ABA (75.0 and $6.5 \mathrm{ng} \mathrm{ml}^{-1}$ medium, respectively) in chemically defined medium as identified by gas chromatography-mass spectrometry (GC-MS) (Perrig and others 2007). ABA was also characterized by gas chromatography with electron impact mass spectrometry (GCEIMS) in the supernatant of the model strain A. brasilense Sp245 from chemically defined media. When $\mathrm{NaCl}$ is added to the culture medium, this strain produces greater amounts of ABA than the control without salt added (235 vs. $73 \mathrm{ng} \mathrm{ml}^{-1}$ ). Inoculation of A. thaliana with A. brasilense Sp245 enhances by twofold the plant's ABA content (3.52 $\mathrm{ng} \mathrm{g}^{-1} \mathrm{FW}$ ) (Cohen and others 2008). To assay the effects of ABA production on plants, maize plants were treated with fluridone, an inhibitor of plant ABA biosynthesis that results in stunted plants, even in normal watering conditions. Inoculation with A. lipoferum USDA 59b completely reversed this effect. The relative water content of fluridone-treated and drought-stressed plants was significantly lower but this effect was neutralized by inoculation with Azospirillum. This suggests that ABA produced by $A$. lipoferum contributes to water-stress alleviation (Cohen and others 2009).

Physiological Roles of Abscisic Acid in Azospirillum sp.

The role of bacterial ABA in plant-Azospirillum interactions is uncertain and there is no direct evidence that this phytohormone promotes or regulates plant growth. However, in restrictive soils (for example, salt- or droughtstressed soils), bacterial ABA could contribute to regulating plant homeostasis and stress response. This is an emerging research line of importance for the PSHR group of PGPRs.

\section{Other Plant Growth Regulator Compounds}

\section{Nitric Oxide}

Nitric oxide (NO) is a volatile, lipophilic free radical that participates in metabolic, signaling, defense, and developmental pathways in plants (Lamattina and Polacco 2007). NO plays a major role in the IAA signaling pathway and its participation leads to lateral and adventitious root 
formation wherein $\mathrm{NO}$ acts as an intermediate in IAAinduced root development (Correa-Aragunde and others 2006).

\section{Nitric Oxide Production in Azospirillum sp.}

A. brasilense Sp245 and Az39 produce NO in vitro, under anaerobic or aerobic culture conditions (Creus and others 2005; Creus unpublished data). In strain Sp245, NO can probably be synthesized via multiple pathways such as aerobic denitrification and heterotrophic nitrification. NO is produced during the middle and late logarithmic phases of growth (Molina-Favero and others 2007, 2008). NO production in A. brasilense Sp245 induces morphological changes in tomato roots regardless of the full bacterial capacity to synthesize IAA. An IAA-attenuated mutant of this strain induces the same physiological changes with slightly less effect on root development as observed for the wild-type strain (Molina-Favero and others 2008).

\section{Polyamines}

Polyamines are low-molecular-weight organic compounds with two or more primary amino groups. They are ubiquitous in plant, animal, and microbial cells (Davies 1995). Polyamines serve as growth-regulating compounds in plants and, like phytohormones, when they are present at the appropriate level they display biological activity in processes such as plant growth, development, and stress mitigation (Kuznetsov and others 2006). In this sense, one of the best documented molecules is diamine cadaverine (1,5-diaminopentane), which has been correlated with root growth promotion in pine and soybean (Niemi and others 2001), response to osmotic stress in turnip (Aziz and others 1997), and control of stomatal activity in Vicia faba beans (Liu and others 2000).

\section{Polyamine Biosynthesis in Azospirillum sp. and Related Rhizobacteria}

Production of putrescine (Put), spermidine (Spd), and spermine $(\mathrm{Spm})$ in chemically defined medium of Azospirillum sp. isolated from manioc roots was reported by Thuler and others (2003a). In a second report, Thuler and others (2003b) reported on the production of Put and Spd in chemically defined medium of Beijerinckia derxii ICB-10 (ATCC 33962), isolated from the Brazilian savannah. The production of cadaverine ( $\mathrm{Cad})$ and other polyamines was reported first by Hamana and others $(1988,1990)$ for a wide group of $\alpha$-proteobacteria belonging to the order Rhizobiales, but recently proposed for A brasilense by Cassán and others (2009a). Similar results were reported by Goris and others (1998) in an extensive group of strains belonging to the so-called Pseudomonas rRNA group I (the authentic pseudomonads) and Azotobacteraceae (free-living nitrogen-fixers). All evaluated strains showed Put, Spd, and Cad production capacity, although for some authentic pseudomonads, Cad could not be identified.

\section{Physiological Role of Polyamines Produced by Azospirillum sp.}

The diamine Cad has been correlated with root growth promotion (Gamarnik and Frydman 1991; Niemi and others 2001) and osmotic stress mitigation (Aziz and others 1997; Liu and others 2000) in plants. A. brasilense Az39 has the capability to produce Cad in chemically defined medium and as an endophyte in rice seedlings. This capacity is correlated with root growth promotion and osmotic stress mitigation under hydroponic culture conditions. Therefore, bacterial Cad production was proposed as a novel bacterial mechanism involved in plant growth promotion and/or regulation of the plant response to osmotic stress (Cassán and others 2009a).

\section{Crosstalk of Bacterial Hormone Production with Plant Phytohormones}

Biochemical, molecular, physiological, and functional analyses of phytohormone interactions in higher plants have re-emerged in the last 10 years, and because of this revival, the bacterial phytohormones are not exempt from the same analyses. The "crosstalk" interactions described in the literature for several plant species may give new insights into the simple phytohormonal growth promotiondependent model described for Azospirillum sp. In this regard, there is circumstantial evidence of the interaction between the phytohormones produced by Azospirillum sp. and the hormonal background of inoculated plants. Moreover, a detailed analysis of this interaction may reveal specific interactions that could result in a PGP effect. In this regard, Fulchieri and others (1993) found that maize seedlings inoculated with three A. lipoferum strains showed significantly improved root and shoot growth compared to seedlings inoculated with a single strain. In these trials $\mathrm{GA}_{3}$ was identified in the free acid fraction of plant extracts and these results led speculation about the bacteria's ability to increase the in vivo pool of biologically active GAs in the roots of inoculated plants. It was shown later that auxin could promote, at least in part, stem elongation by increasing endogenous levels of $3 \beta$-hydroxylated GAs (Ross and O'Neill 2001), which could directly be related to the results of Fulchieri and others (1993). Thus, part of the growth response observed in inoculated plants might be the result of the bacterial production of GAs or the plant 
production of GAs induced by bacterial IAA (Yaxley and others 2001; Ford and others 2002; Inada and Shimmen 2000). However, it is very difficult to discriminate between different phytohormone pools and therefore careful analyses are necessary to pinpoint the changes in phytohormone levels due to inoculation.

Another case of crosstalk is the study of the growth response of tomato seedlings inoculated with $A$. brasilense FT326, correlating plant phenotypes and Et production. The increase in Et production was accompanied by increased activity of ACC synthase in plant tissues (Krumpholz and others 2006). These results indicate that the Et increase is in part due to crosstalk between the bacterially produced IAA and Et synthesis by the plant (Rahman and others 2002).

Although a number of interactions between bacterial and plant phytohormones were discussed in this section, the ability of bacteria to modify the plant's balance between auxin and CKs (due to the production/degradation of IAA and/or CKs) is worth mentioning because this balance determines the root/shoot ratio. However, no in-depth studies on this balance have been published, except a detailed analysis on the auxin/cytokinin production by soiland plant-associated bacteria (Van Laer 2003).

\section{Azospirillum-Based Inoculants and Plant Growth Promotion}

A flourishing inoculant business has developed in South America, possibly due to the large area dedicated to extensive agriculture and the reproducible results under field conditions. This section focuses on the Argentina experience as a case study of the level of agronomic use of Azospirillum-based inoculants.

From 1981 to 1996 , the Instituto de Microbiología y Zoología Agrícola (IMYZA), INTA-Castelar from Argentina, developed an intensive program with the main objective of selecting and identifying Azospirillum strains and to evaluate their ability to promote plant growth in different crop species. The experiments showed that there was a more pronounced effect with $A$. brasilense than with A. lipoferum on most evaluated plant species, and they showed that A. brasilense Az39 was the most promising strain for inoculant formulation based on its ability to increase growth and yield of evaluated crops in the range of 13-33\%. Based on this information, the National Agricultural Health Service (SENASA) proclaimed a nationwide recommendation of the native strain A. brasilense Az39 for inoculant production for use on maize, wheat, and other nonlegume plant species. From a physiological point of view, the plant-growth-promoting capacity of A. brasilense Az39 has been confirmed agronomically by its effectiveness for the past 30 years in increasing the productivity of inoculated crops in a large number of assays under field conditions (Díaz-Zorita and Fernández Canigia 2009). However, a detailed description of the main plant-growth-promoting mechanisms of this strain was lacking. The Laboratorio de Fisiología Vegetal y de la Interacción Planta-microorganismo of the Universidad Nacional de Río Cuarto (Argentina) has elucidated the potential mechanisms responsible for the growth promotion by this strain. As part of these results, Perrig and others (2007) showed that $A$. brasilense Az39 has the ability to produce and release IAA, Z, GA 3 , ABA, and Et in vitro. Strain Az39, used an inoculant alone or in combination with $B$. japonicum E109, has the capacity to promote seed germination and early growth in soybean, wheat, and maize (Cassán and others 2009 b). This strain was also able to produce and release $\mathrm{GA}_{3}$, $\mathrm{Z}$, and IAA in culture medium in sufficient concentrations to produce morphological and physiological changes in treated seeds or seedlings. The concentrations of $\mathrm{GA}_{3}, \mathrm{Z}$, and IAA increase during the stationary growth phase because bacteria produce phytohormones during the exponential and early stationary growth phase, but these molecules are continuously accumulated in the culture medium because of the "batch fermentation model." Finally, the accumulation of phytohormones alters the capacity of the bacterial culture (inoculant) to promote seed or seedling growth, and because this effect is not strictly dependent on the bacterial cell, it could be defined as the "hormonal effect of inoculation" and might be extended to other phytohormone-producing PGPR.

\section{Conclusion and Future Prospects}

Phytohormone production by bacteria has been a research topic for many decades, first in pathogenic (for example, A. tumefaciens) and later also in beneficial plant-associated bacteria. Relatively little is known about phytohormones in Azospirillum sp. and other bacteria as compared to model plants. Aspects that are well characterized are the biosynthesis pathways involved in phytohormone production, although for many phytohormones we need to rely on plant data to fully understand the bacterial biosynthesis. A prerequisite to estimate the importance of bacterial phytohormone production in plant growth promotion is the use of mutants impaired in production, for example, a knockout mutant missing a key biosynthetic gene. Only in the case of auxins (particularly for IAA) has the physiological and molecular functionality in both chemically defined medium and plant-microbe interaction been described. For gibberellins, and particularly for gibberellic acid and $\mathrm{GA}_{1}$, the model has been described from a physiological but not from a molecular point of view. Finally, for CKs, ABA, Et, polyamines, and NO, the ability of several microorganisms to produce these compounds in chemically defined medium 
Table 2 Overview of plant growth regulators produced in vitro by Azospirillum sp.

\begin{tabular}{|c|c|c|c|}
\hline Class $^{\mathrm{a}}$ & Hierarchy $^{\mathrm{b}}$ & Molecules & References \\
\hline Auxins & $1 \mathrm{st}$ & IAA, PAA, IBA & $\begin{array}{l}\text { Prinsen and others (1993) } \\
\text { Martínez-Morales and others (2003) } \\
\text { Somers and others (2005) }\end{array}$ \\
\hline Gibberellins & 4th & $\mathrm{GA}_{3}, \mathrm{GA}_{1}, \mathrm{GA}_{9}, \mathrm{GA}_{20}, \mathrm{GA}_{19}, \mathrm{GA}_{5}$ & $\begin{array}{l}\text { Bottini and others (1989) } \\
\text { Piccoli and Bottini (1996) }\end{array}$ \\
\hline Cytokinins & 3 rd & $\mathrm{iP}, \mathrm{iPr}, \mathrm{Z}, t-\mathrm{Zr}$ & $\begin{array}{l}\text { Horemans and others (1986) } \\
\text { Esquivel-Cote and others (2010) }\end{array}$ \\
\hline Ethylene & 5 th & Et & Strzelczyk and others (1994) \\
\hline Abscisic acid & 6th & $\mathrm{ABA}$ & Kolb and Martin (1985) \\
\hline Nitric oxide & 2nd & NO & Creus and others (2005) \\
\hline Polyamines & 7th & Cad, Spm, Spd, Put & $\begin{array}{l}\text { Cassán and others (2009a) } \\
\text { Thuler and others (2003a) }\end{array}$ \\
\hline
\end{tabular}

$I A A$ indole-3-acetic acid, $P A A$ phenylacetic acid, $I B A$ indole-3-butyric acid, $N O$ nitric oxide, $i P$ isopentenyl adenine, $i P r$ isopentenyl adenine riboside, $Z$ zeatin, t-Zr trans zeatin riboside, $G A_{3,1,9,20,19}$ gibberellins n, Et ethylene, $A B A$ abscisic acid, $C a d$ cadaverine, Spm spermine, $S p d$ spermidine, Put putrescine

${ }^{a}$ Molecules identified from Azospirillum sp. liquid cultures by precise methodology (HPLC, GC-MS)

b Related to the importance of the phytohormonal role in its interaction with the plant considered by the authors based on available evidence

has been demonstrated but not fully understood in plantmicrobe interactions (see Table 2 for an overview).

Integration of both microbial and plant models from a phytohormone and physiological point of view could be the beginning of a better understanding of the plant-microbe interactions into a new concept named "plant-microbe physiology" or simply "integrative physiology." As we described throughout this review, Azospirillum sp. have the capacity to modify growth, development, and behavior of several plants, even in stress conditions. However, molecular evidence at the level of plant-hormoneplant-microbe interaction is lacking and this level is certainly a domain emerging for study in the future.

Acknowledgments The review was written in the framework of a bilateral FWO-Vlaanderen-MINCyT research project (VS.011.11N) granted to FC and JV. FC is a researcher of Consejo Nacional de Investigaciones Científico-Tecnológicas (CONICET) and Universidad Nacional de Río Cuarto (UNRC) and SS is a recipient of a postdoctoral fellowship grant from Research Foundation Flanders (FWO-Vlaanderen). Special thanks to Yoav Bashan (CBNOR) and Cecilia Creus (INTA-UNMdP) for providing information to complete the phytohormonal model of Azospirillum sp.

Conflict of interest The authors have no conflict of interest to disclose.

\section{References}

Arshad M, Frankenberger R Jr (1993) Microbial production of plant growth regulators. In: Meeting B (ed) Soil microbial ecology. Marcel Dekker, New York, pp 307-347
Aziz A, Martin-Tanguy J, Larher F (1997) Plasticity of polyamine metabolism associated with high osmotic stress in rape leaf discs and with ethylene treatment. Plant Growth Regul 21:153-163

Baca B, Soto-Urzua L, Xochiua-Corona Y, Cuervo-García A (1994) Characterization of two aromatic amino acid aminotransferases and production of indoleacetic acid in Azospirillum strains. Soil Biol Biochem 26:57-63

Baldani V, Alvarez M, Baldani J, Döbereiner J (1986) Establishment of inoculated Azospirillum spp. in the rhizosphere and in roots of field grown wheat and sorghum. Plant Soil 90:35-46

Bally R, Thomas-Bauzon D, Heulin T, Balandreau J (1983) Determination of the most frequent $\mathrm{N}_{2}$ fixing bacteria in the rice rhizosphere. Can J Microbiol 29:881-887

Bar T, Okon Y (1993) Tryptophan conversion to indole-3-acetic acid via indole-3-acetamide in Azospirillum brasilense Sp7. Can J Microbiol 39:81-86

Barbieri P, Bernardi A, Galli E, Zanetti G (1988) Effects of inoculation with different strains of $A$. brasilense on wheat roots development. In: Klingmüller W (ed) Azospirillum IV. Genetics, physiology, ecology. Springer, Berlin, pp 181-188

Barea J, Navarro M, Montoya E (1976) Production of plant growth regulators by rhizosphere phosphate-solubilizing bacteria. J Appl Bacteriol 40:129-134

Bashan Y, de Bashan L (2010) How the plant growth-promoting bacterium Azospirillum promotes plant growth: a critical assessment. Adv Agron 108:77-136

Bashan Y, Holguín G (1998) Proposal for the division of plant growth-promoting rhizobacteria into two classifications: biocontrol-PGPB (plant growth promoting bacteria) and PGPB. Soil Biol Biochem 30:1225-1228

Bashan Y, Levanony H (1990) Current status of Azospirillum inoculation technology: Azospirillum as a challenge for agriculture. Can J Microbiol 36:591-608

Baudoin E, Lerner A, Mirza MS, El Zemrany H, Prigent-Combaret C, Jurkevich E, Spaepen S, Vanderleyden J, Nazaret S, Okon Y et al (2010) Effects of Azospirillum brasilense with genetically modified auxin biosynthesis gene ipdC upon the diversity of the indigenous microbiota of the wheat rhizosphere. Res Microbiol 161:219-226 
Bergersen F (1971) Biochemistry of symbiotic nitrogen fixation in legumes. Ann Rev Plant Physiol 22:121-140

Blaha D, Prigent-Combaret C, Mirza M, Möenne-Loccoz Y (2006) Phylogeny of the 1-aminocyclopropane-1-carboxylic acid deaminase-encoding gene acdS in phytobeneficial and pathogenic Proteobacteria and relation with strain biogeography. FEMS Microbiol Ecol 56:455-470

Bothe H, Körsgen H, Lehmaher T, Hundeshagen B (1992) Differential effects of Azospirillum, auxin and combined nitrogen on the growth of the roots of wheat. Symbiosis 13:167-179

Bottini R, Fulchieri M, Pearce D, Pharis R (1989) Identification of gibberellins $\mathrm{A}_{1}, \mathrm{~A}_{3}$, and Iso- $\mathrm{A}_{3}$ in cultures of A. lipoferum. Plant Physiol 90:45-47

Bottini R, Cassán F, Piccoli P (2004) Gibberellin production by bacteria and its involvement in plant growth promotion and yield increase. Appl Microbiol Biotechnol 65(5):497-503

Burdman S, Volpin H, Kigel J, Kapulnik Y, Okon Y (1996) Promotion of nod gene inducers and nodulation in common bean (Phaseolus vulgaris) roots inoculated with Azospirillum brasilense Cd. Appl Environ Microbiol 62:3030-3033

Burg S (1962) The physiology of ethylene formation. Ann Rev Plant Physiol 13:265-302

Burg S, Burg P (1968) Ethylene formation in pea seedlings: its relation to the inhibition of bud growth caused by indole-3-acetic acid. Plant Physiol 43:1069-1073

Cacciari I, Lippi D, Pietrosanti T (1989) Phytohormone-like substances produced by single and mixed diazotrophic cultures of Azospirillum spp. and Arthrobacter. Plant Soil 115:151-153

Carreño-López R, Campos-Reales C, Elmerich C, Baca B (2000) Physiological evidence for differently regulated tryptophandependent pathways for indole-3-acetic acid synthesis in Azospirillum brasilense. Mol Gen Genet 264:521-530

Cassán F, Bottini R, Piccoli P (2001a) In vivo gibberellin A9 metabolism by Azospirillum sp. in $d y$ dwarf rice mutants seedlings. PGRSA Q 28:124-129

Cassán F, Bottini R, Schneider G, Piccoli P (2001b) Azospirillum brasilense and Azospirillum lipoferum hydrolize conjugates of $\mathrm{GA}_{20}$ and metabolize the resultant aglycones to $\mathrm{GA}_{1}$ in seedlings of rice dwarf mutants. Plant Physiol 125:2053-2058

Cassán F, Lucangelli C, Bottini R, Piccoli P (2001c) Azospirillum spp. metabolize $\left[17,17-{ }^{2} \mathrm{H}_{2}\right]$ gibberellin $\mathrm{A}_{20}$ to $\left[17,17-{ }^{2} \mathrm{H}_{2}\right]$ gibberellin $\mathrm{A}_{1}$ in vivo in $d y$ rice mutant seedlings. Plant Cell Physiol 42:763-767

Cassán F, Maiale S, Masciarelli O, Vidal A, Luna V, Ruiz O (2009a) Cadaverine production by Azospirillum brasilense and its possible role in plant growth promotion and osmotic stress mitigation. Eur J Soil Biol 45:12-19

Cassán F, Perrig D, Sgroy V, Masciarelli O, Penna C, Luna V (2009b) Azospirillum brasilense Az39 and Bradyrhizobium japonicum $\mathrm{E}$ 109 promote seed germination and early seedling growth, independently or co-inoculated in maize (Zea mays L.) and soybean (Glycine max L.). Eur J Soil Biol 45:28-35

Castro-Guerrero J, Romero A, Aguilar J, Xiqui M, Sandoval J, Baca $\mathrm{B}$ (2012) The hisCl gene, encoding aromatic amino acid aminotransferase-1 in Azospirillum brasilense Sp7, expressed in wheat. Plant Soil 356:139-150

Charyulu P, Fourcassie F, Barbouche A, Rondro Harisoa L, Omar A, Weinhard P, Marie R, Balandreau J (1985) Field inoculation of rice using in vitro selected bacterial and plant genotypes. In: Klingmüller W (ed) Azospirillum III: genetics, physiology, ecology. Springer, Berlin, pp 163-179

Cohen A, Bottini R, Piccoli P (2008) Azospirillum brasilense Sp 245 produces $\mathrm{ABA}$ in chemically-defined culture medium and increases ABA content in Arabidopsis plants. Plant Growth Regul 54:97-103

Cohen A, Travaglia C, Bottini R, Piccoli P (2009) Participation of abscisic acid and gibberellins produced by endophytic
Azospirillum in the alleviation of drought effects in maize. Botany 87:455-462

Combes-Meynet E, Pothier JF, Moënne-Loccoz Y, Prigent-Combaret C (2011) The Pseudomonas secondary metabolite 2,4-diacetylphloroglucinol is a signal inducing rhizoplane expression of Azospirillum genes involved in plant-growth promotion. Mol Plant Microbe Interact 24:271-284

Conney T, Nonhebel H (1991) Biosynthesis of indole-3-acetic acid in tomato shoots: measurement, mass-spectral identification and incorporation of ${ }^{2} \mathrm{H}$ from ${ }^{2} \mathrm{H}_{2} \mathrm{O}$ into indole-3-acetic acid, D- and L-tryptophan, indole-3-pyruvate and tryptamine. Planta 184:368-376

Cooper J (2007) Early interactions between legumes and rhizobia: disclosing complexity in a molecular dialogue. J Appl Microbiol 103:1355-1365

Correa-Aragunde N, Graziano M, Chevalier C, Lamattina L (2006) Nitric oxide modulates the expression of cell cycle regulatory genes during lateral root formation in tomato. J Exp Bot 57:581-588

Costacurta A, Keijers V, Vanderleyden J (1994) Molecular cloning and sequence analysis of an Azospirillum brasilense indole-3pyruvate deccarboxylase. Mol Gen Genet 243:463-472

Creus C, Graziano M, Casanovas E, Pereyra A, Simontacchi M, Puntarulo S, Barassi C, Lamattina L (2005) Nitric oxide is involved in the Azospirillum brasilense-induced lateral root formation in tomato. Planta 221:297-303

Crozier A, Arruda P, Jasmim JM, Monteiro AM, Sandberg G (1988) Analysis of indole-3-acetic acid and related indoles in culture medium from Azospirillum lipoferum and Azospirillum brasilense. Appl Environ Microbiol 54:2833-2837

Dardanelli M, Fernandez de Cordoba F, Espuny M, Rodriguez Carvajal M, Soria Diaz M, Gil Serrano A, Okon Y, Megias M (2008) Effect of Azospirillum brasilense coinoculated with Rhizobium on Phaseolus vulgaris flavonoids and Nod factor production under salt stress. Soil Biol Biochem 40:2713-2721

Davies P (1995) Plant hormones. physiology, biochemistry and molecular biology. Kluwer Academic, Dordrecht, p 833

Díaz-Zorita M, Fernández Canigia M (2009) Field performance of a liquid formulation of Azospirillum brasilense on dryland wheat productivity. Eur J Soil Biol 45(1):3-11

Dobbelaere S, Croonenborghs A, Thys A, Vande Broek A, Vanderleyden J (1999) Phytostimulatory effect of Azospirillum brasilense wild type and mutant strains altered in IAA production on wheat. Plant Soil 212:155-164

Esquivel-Cote R, Ramírez-Gama R, Tsuzuki-Reyes G, OrozcoSegovia A, Huante P (2010) Azospirillum lipoferum strain AZm5 containing 1-aminocyclopropane-1-carboxylic acid deaminase improves early growth of tomato seedlings under nitrogen deficiency. Plant Soil 337:65-75

Falik E, Okon Y, Epstein E, Goldman A, Fischer M (1989) Identification and quantification of IAA and IBA in Azospirillum brasilense-inoculated maize roots. Soil Biol Biochem $21: 147-153$

Ford Y, Taylor J, Blake P, Marks P (2002) Gibberellin A 3 stimulates adventitious rooting of cuttings from cherry (Prunus avium). Plant Growth Regul 37:127-133

Frankenberger W, Arshad M (1995) Phytohormones in soil. Marcel Dekker, New York, p 503

Fulchieri M, Lucangelli C, Bottini R (1993) Inoculation with A. lipoferum affects growth and gibberellin status of corn seedlings roots. Plant Cell Physiol 34:1305-1309

Gamarnik A, Frydman R (1991) Cadaverine, an essential diamine for the normal root development of germinating soybean (Glycine max) seeds. Plant Physiol 97:778-785

Ge SM, Chen SF (2009) Expression and functional analysis of aminotransferase involved in indole-3-acetic acid biosynthesis in 
Azospirillum brasilense Yu62. Biochemistry (Moscow) 74(1):81-84

Glick B, Karaturovic D, Newell P (1995) A novel procedure for rapid isolation of plant growth promoting pseudomonads. Can J Microbiol 41:533-536

Glick B, Patten C, Holguin G, Penrose D (1999) Biochemical and genetic mechanisms used by plant growth promoting bacteria. Imperial College Press, London, p 267

Goris J, Kersters K, De Vos P (1998) Polyamines distribution among authentic Pseudomonads and Azotobacteraceae. Syst Appl Microbiol 21:285-290

Hamana K, Matsuzaki K, Sakakibara M (1988) Distribution of symhomospermidine in eubacteria, cyanobacteria, algae and ferns. FEMS Microbiol Lett 50:11-16

Hamana K, Minamisawa K, Matsuzaki S (1990) Polyamines in Rhizobium, Bradyrhizobium, Azorhizobium and Agrobacterium. FEMS Microbiol Lett 71:71-76

Hartmann A, Singh M, Klingmüller W (1983) Isolation and characterization of Azospirillum mutants excreting high amounts of indoleacetic acid. Can J Microbiol 29:916-923

Hartmann A, Rothballer M, Schmid M (2008) Lorenz Hiltner, a pioneer in rhizosphere microbial ecology and soil bacteriology research. Plant Soil 312:7-14

Hedden P, Phillips AL (2000) Gibberellin metabolism: new insights revealed by the genes. Trends Plant Sci 5:523-530

Holguín G, Glick BR (2001) Expression of the ACC deaminase gene from Enterobacter cloacae UW4 in Azospirillum brasilense. Microb Ecol 41:281-288

Horemans S, Koninck K, Neuray J, Hermans R, Vlassak K (1986) Production of plant growth substances by Azospirillum sp. and other rhizophere bacteria. Symbiosis 2:341-346

Hubbell D, Tien T, Gaskins M, Lee J (1979) Physiological interaction in the Azospirillum-grass root association. In: Vose P, Ruschel A (eds) Associative $\mathrm{N}_{2}$-fixation. CRC Press, Boca Raton, pp 1-6

Inada S, Shimmen T (2000) Regulation of elongation growth by gibberellin in root segments of Lemna minor. Plant Cell Physiol 41:932-939

Janzen R, Rood S, Dormaar J, McGill W (1992) Azospirillum brasilense produces gibberellins in pure culture on chemicallydefined medium and in co-culture on straw. Soil Biol Biochem 24:1061-1064

Kaneko T, Minamisawa K, Isawa T, Nakatsukasa H, Mitsui $\mathrm{H}$ et al (2010) Complete genomic structure of the cultivated rice endophyte Azospirillum sp. B510. DNA Res 17:37-50

Klee H, Montoya A, Horodyski F, Lichenstein C, Garfinkel D, Fuller S, Flores C, Peschon J, Nester E, Gordon M (1984) Nucleotide sequence of the tms genes of the pTiANC octopine $\mathrm{C}$ plasmid: two genes products involved in plants tumorogenesis. P Natl Acad Sci USA 81:1728-1732

Kloepper J, Schroth M (1978) Plant growth-promoting rhizobacteria in radish. In Proceedings of the 4th international conference on plant pathogenic bacteria, vol 2. Angers, INRA, France, pp 879882

Kloepper J, Lifshitz R, Schroth M (1989) Pseudomonas inoculants to benefit plant production. ISI Atlas Sci Anim Plant Sci 8:60-64

Kobayashi M, Sakurai A, Saka A, Takahashi N (1989) Quantitative analysis of endogenous gibberellins in normal and dwarf cultivars of rice. Plant Cell Physiol 30:963-969

Kolb W, Martin P (1985) Response of plant roots to inoculation with Azospirillum brasilense and to application of indoleacetic acid. In: Klingmüller W (ed) Azospirillum III: genetics, physiology, ecology. Springer, Berlin, pp 215-221

Korasick DA, Enders TA, Strader LC (2013) Auxin biosynthesis and storage forms. J Exp Bot 64:2541-2555

Krumpholz E, Ribaudo C, Cassán F, Bottini R, Cantore M, Curá A (2006) Azospirillum sp. promotes root hair development in tomato plants through a mechanism that involves ethylene. J Plant Growth Regul 25:175-185

Kucey R (1988) Alteration of size of wheat root systems and nitrogen fixation by associative nitrogen-fixing bacteria measured under field conditions. Can J Microbiol 34:735-739

Kuznetsov V, Radyukina N, Shevyakova N (2006) Polyamines and stress: biological role, metabolism, and regulation. Russ J Plant Physiol 53:583-604

Lamattina L, Polacco J (2007) Nitric oxide in plant growth development and stress physiology. Springer, Berlin, p 283

Lambrecht M, Vande Broek A, Dosselaere F, Vanderleyden J (1999) The ipdC promoter auxin-responsive element of Azospirillum brasilense, a prokaryotic ancestral form of the plant AusxRE? Mol Microbiol 32:889-890

Lambrecht M, Okon Y, Vande Broek A, Vanderleyden J (2000) Indole-3-acetic acid: a reciprocal signalling molecule in bacteriaplant interactions. Trends Microbiol 8:298-300

Letham D (1963) Zeatin, a factor inducing cell division from Zea mays. Life Sci 8:569-573

Liu K, Fu H, Bei Q, Luan S (2000) Inward potassium channel in guard cells as a target for polyamine regulation of stomatal movements. Plant Physiol 124:1315-1325

Lucangelli C, Bottini R (1997) Effects of Azospirillum spp. on endogenous gibberellin content and growth of maize (Zea mays L.) treated with uniconazole. Symbiosis 23:63-72

Magalhães F, Baldani J, Souto S, Kuykendall J, Döbereiner J (1983) A new acid-tolerant Azospirillum species. An Acad Bras Ciênc 55:417-430

Malhotra M, Srivastava S (2008) Organization of the ipdC region regulates IAA levels in different Azospirillum brasilense strains: molecular and functional analysis of ipdC in strain SM. Environ Microbiol 10:1365-1373

Malhotra M, Srivastava S (2009) Stress-responsive indole-3-acetic acid biosynthesis by Azospirillum brasilense SM and its ability to modulate plant growth. Eur J Soil Biol 45:73-80

Martínez-Morales L, Soto-Urzua L, Baca B, Sanchez-Ahedo J (2003) Indole-3-butyric acid (IBA) production in culture medium by wild strain Azospirillum brasilense. FEMS Microbiol Lett 228:167-173

Mathesius U, Shalaman H, Meijer D, Lugtenberg B, Spaink H, Weinman J, Rodam L, Sautter C, Rolfe B, Djordjevic M (1997) New tools for investigating nodule initiation and ontogeny: spot inoculation and microtargeting of transgenic withe clover roots shows auxin involvement and suggest a role for flavonoids. In: Stacey G, Mullin B, Gresshoff P (eds) Advances in molecular genetics of plant-microbe interactions. Kluwer Academic, Dordrecht

Miller C, Skoog F, Von Saltza M, Strong F (1955) Kinetin, a cell division factor from deoxyribonucleic acid. J Am Chem Soc 77:1392

Molina-Favero C, Creus C, Lanteri M, Correa-Aragunde N, Lombardo M, Barassi C, Lamattina L (2007) Nitric oxide and plant growth promoting rhizobacteria: common features influencing root growth and development. Adv Bot Res 46:1-33

Molina-Favero C, Creus C, Simontacchi M, Puntarulo S, Lamattina L (2008) Aerobic nitric oxide production by Azospirillum brasilense Sp245 and its influence on root architecture in tomato. Mol Plant Microbe Interact 21:1001-1009

Murakami Y (1968) A new rice seedling bioassay for gibberellins, microdrop method and its use for testing extracts of rice and morning glory. Bot Mag 81:3-43

Murakami Y (1972) Dwarfing genes in rice and their relation to gibberellin biosynthesis. In: Carr D (ed) Plant growth substances 1970. Springer, Berlin, pp 164-174

Muralidhara R, Rai P (1986) Plant growth regulators produced by diazotrophic bacteria. National seminar on microbial ecology, 
January 23-24, 1986, Tamil Nadu Agricultural University, Tamil Nadu, India, pp 18-23

Nambara E, Marion-Poll A (2005) Abscisic acid biosynthesis and catabolism. Annu Rev Plant Biol 56:165-185

Niemi K, Haggman H, Sarjala T (2001) Effects of exogenous diamines on the interaction between ectomycorrhizal fungi and adventitious root formation in Scots pine in vitro. Tree Physiol $22: 373-381$

Nonhebel H, Cooney T, Simpson R (1993) The route, control and compartmentation of auxin synthesis. Aust J Plant Physiol 20:527-539

Okon Y, Labandera-González C (1994) Agronomic applications of Azospirillum: an evaluation of 20 years worlwide field inoculation. Soil Biol Biochem 26:1591-1601

Omay S, Schmidt W, Martin P, Bangerth F (1993) Indoleacetic acid production by the rhizosphere bacterium Azospirillum brasilense Cd under in vitro conditions. Can J Microbiol 39:187-192

Ona O, Smets I, Gysegom P, Bernaerts K, Impe J, Prinsen E, Vanderleyden $\mathrm{J}$ (2003) The effect of $\mathrm{pH}$ on indole-3-acetic acid (IAA) biosynthesis of Azospirillum brasilense sp7. Symbiosis 35:199-208

Ona O, van Impe J, Prinsen E, Vanderleyden J (2005) Growth and indole-3-acetic acid biosynthesis of Azospirillum brasilense Sp245 is environmentally controlled. FEMS Microbiol Lett 246:125-132

Patten C, Glick B (1996) Bacterial biosynthesis of indole 3-acetic acid. Can J Microbiol 42:207-220

Pearce D, Koshioka M, Pharis R (1994) Chromatography of gibberellins. J Chromatogr A 658:91-122

Pedraza R, Ramirez-Mata A, Xiqui M, Baca B (2004) Aromatic amino acid aminotransferase activity and indole-3-acetic acid production by associative nitrogen-fixing bacteria. FEMS Microbiol Lett 233:15-21

Perley J, Stowe B (1966) On the ability of Taphrina deformans to produce indole acetic acid from tryptophan by way of tryptamine. Plant Physiol 41:234-237

Perrig D, Boiero L, Masciarelli O, Penna C, Cassán F, Luna V (2007) Plant growth promoting compounds produced by two agronomically important strains of Azospirillum brasilense, and their implications for inoculant formulation. Appl Microbiol Biotechnol 75:1143-1150

Phinney B, Spray C (1988) Dwarf mutants of maize-research tools for the analysis of growth. In: Pharis R, Rood S (eds) Plant growth substances 1988. Springer, Berlin, pp 65-73

Piccoli P, Bottini R (1994a) Metabolism of 17,17-[ $\left[{ }^{2} \mathrm{H}_{2}\right]$-gibberellin $\mathrm{A}_{20}$ to $17,17-\left[{ }^{2} \mathrm{H}_{2}\right]$-gibberellin $\mathrm{A}_{1}$ by A. lipoferum cultures. AgriScientiae 11:13-15

Piccoli P, Bottini R (1994b) Effect of C/N ratio, N content, $\mathrm{pH}$ and incubation time on growth and gibberellin production by Azospirillum lipoferum cultures. Symbiosis 21:263-264

Piccoli P, Bottini R (1996) Gibberellins production in A. lipoferum cultures and enhanced by light. Biocell 20:185-190

Piccoli P, Lucangelli C, Schneider G, Bottini R (1997) Hydrolisis of $17,17-\left[{ }^{2} \mathrm{H}_{2}\right]$-gibberellin $\mathrm{A}_{20}$-glucoside and $17,17-\left[{ }^{2} \mathrm{H}_{2}\right]$-gibberellin $\mathrm{A}_{20}$-glucosyl ester by Azospirillum lipoferum cultured in nitrogen-free biotin-based chemycally-definded medium. Plant Growth Regul 23:179-182

Piccoli P, Masciarelli O, Bottini R (1999) Gibberellin production by Azospirillum lipoferum cultured in chemically-defined medium as affected by oxygen availability and water status. Symbiosis 27:135-146

Piotrowski M (2008) Primary or secondary? Versatile nitrilases in plant metabolism. Phytochemistry 69:2655-2667

Primrose S, Dilworth M (1976) Ethylene production by bacteria. J Gen Microbiol 93:177-181
Prinsen E, Costacurta A, Michiels K, Vanderleyden J, Van Onckelen H (1993) Azospirillum brasilense indole-3-acetic acid biosynthesis: evidence for a non-tryptophan dependent pathway. Mol Plant Microbe Interact 6:609-615

Rademacher W (2000) Growth retardants: effects on gibberellin biosynthesis and other metabolic pathways. Ann Rev Plant Physiol Plant Mol Biol 51:501-531

Rahman A, Hosokawa S, Oono Y, Amakawa T, Goto N, Tsurumi S (2002) Auxin and ethylene response interactions during Arabidopsis root hair development diss. Plant Physiol 130:1908-1917

Remans R, Beebe S, Blair M, Marique G, Tovar E, Rao I, Croonenbarghs A, Torres-Gutierrez R, El-Idoweity M, Michiels J, Vanderlyden J (2008a) Physiological and genetic analysis of root responsiveness to auxin-producing plant growth promoting bacteria in common bean (Phaseolus vulgaris L.). Plant Soil 302:149-161

Remans R, Schelkens S, Hernandez G, Garcia A, Luis Reyes J, Mendez N, Toscano V, Mulling M, Galvez L, Vanderleyden J (2008b) Effect of Rihzobium-Azospirillum coinoculation on nitrogen fixation and yield of two contrasting Phaseolus vulgaris L. genotypes cultivated across different environments in cube. Plant Soil 312:25-37

Rodrigues E, Rodrigues L, de Oliveira A, Baldani V, Teixeira K, Urquiaga S, Reis V (2008) Azospirillum amazonense inoculation: effects on growth, yield and $\mathrm{N}_{2}$ fixation of rice (Oryza sativa L.). Plant Soil 302:249-261

Rood S, Pharis R (1987) Evidence for reversible conjugation of gibberellins in higher plants. In: Schreiber H, Schutte H, Semder $\mathrm{G}$ (eds), Conjugated plant hormones. Structure, metabolism and function. In Proceedings of the international symposium conjugated plant hormones: structure, metabolism and function held in Gera, Germany. Berlin, VEB Deustcher Verlag der Wissenschaften, pp 183-190

Ross J, O'Neill D (2001) New interactions between classical plant hormones. Trends Plant Sci 6:2-4

Rothballer M, Schmid M, Fekete A, Hartmann A (2005) Comparative in situ analysis of ipdC-gfpmut3 promoter fusions of Azospirillum brasilense Sp7 and Sp245. Environ Microbiol 7:1839-1846

Ruckäschel E, Klingmüller W (1992) Analysis of IAA biosynthesis in Azospirillum lipoferum and Tn5 induced mutants. Symbiosis 13:123-131

Sakakibara H (2006) Cytokinins: activity, biosynthesis, and translocation. Annu Rev Plant Biol 57:431-449

Sant'Anna F, Almeida L, Cecagno R, Reolon L, Siqueira F, Machado M, Vasconcelos A, Schrank I (2011) Genomic insights into the versatility of the plant growth-promoting bacterium Azospirillum amazonense. BMC Genomics 12:409

Schmidt W, Martin P, Omay H, Bangerth F (1988) Influence of Azospirillum brasilense on nodulation of legumes. In: Klingmüller W (ed) Azospirillim IV. Genetics, physiology, ecology. Springer, Heidelberg, pp 92-100

Sembder G, Gross D, Liebisch H, Schneider G (1980) Biosynthesis and metabolism of plant hormones. In: MacMillan J (ed) Encyclopedia of plant physiology, new series. Springer, Berlin, pp 281-444

Somers E, Ptacek D, Gysegom P, Srinivasan M, Vanderleyden J (2005) Azospirillum brasilense produces the auxin-like phenylacetic acid by using the key enzyme for indole-3-acetic acid biosynthesis. Appl Environ Microb 71:1803-1810

Spaepen S, Vanderleyden J, Remans R (2007) Indole-3-acetic acid in microbial and microorganism-plant signaling. FEMS Microbiol Rev 31:425-448

Spaepen S, Dobbelaere S, Croonenborghs A, Vanderleyden J (2008) Effects of Azospirillum brasilense indole-3-acetic acid production on inoculated wheat plants. Plant Soil 312:15-23 
Strzelczyk E, Kamper M, Li C (1994) Cytokinin-like substances and ethylene production by Azospirillum in media with different carbon sources. Microbiol Res 149:55-60

Teale W, Paponov I, Palme K (2006) Auxin in action: signalling, transport and the control of plant growth and development. Nat Rev Mol Cell Biol 7:847-859

Thiman K (1936) On the physiology of the formation of nodule in legumes roots. Proc Natl Acad Sci USA 22:511-514

Thuler D, Floh E, Handro W, Barbosa H (2003a) Beijerinckia derxii releases plant growth regulators and amino acids in synthetic media independent of nitrogenase activity. J Appl Microbiol 95:799-806

Thuler D, Floh E, Handro W, Barbosa H (2003b) Plant growth regulators and amino acids released by Azospirillum sp. in chemically defined media. Lett Appl Microbiol 37:174-178

Tien T, Gaskins M, Hubbell D (1979) Plant growth substances produced by Azsopirillum brasilense and their effect on the growth of pearl millet (Pennisetum americanum L.). Appl Environ Microbiol 37:1016-1024

Van Laer S (2003) PhD thesis, University of Antwerpen, Belgium

Van Puyvelde S, Cloots L, Engelen K, Das F, Marchal K, Vanderleyden J, Spaepen S (2011) Transcriptome analysis of the rhizosphere bacterium Azospirillum brasilense reveals an extensive auxin response. Microb Ecol 61:723-728

Vande Broek A, Lambrecht M, Eggermont K, Vanderleyden J (1999) Auxins upregulate expression of the indole-3-pyruvate decarboxylase gene in Azospirillum brasilense. J Bacteriol 181:1338-1342

Vande Broek A, Gysegom P, Ona O, Hendrickx N, Prinsen E, Van Impe J, Vanderleyden J (2005) Transcriptional analysis of the Azospirillum brasilense indole-3-pyruvate decarboxylase gene and identification of a cis-acting sequence involved in auxin responsive expression. Mol Plant Microbe Interact 18(4):311-323

Vorwerk S, Biernacki S, Hillebrand H, Janzik I, Muller A, Weiler E, Piotrowski M (2001) Enzymatic characterization of the recombinant Arabidopsis thaliana nitrilase subfamily encoded by the NIT2/NIT1/NIT3-gene cluster. Planta 212:508-516

Wisniewski-Dyé F, Borziak K, Khalsa-Moyers G, Alexandre G, Sukharnikov L et al (2011) Azospirillum genomes reveal transition of bacteria from aquatic to terrestrial environments. PLoS Genet 7(12):e1002430

Wisniewski-Dyé F, Lozano L, Acosta-Cruz E, Borland S, Drogue B, Prigent-Combaret et al (2012) Genome sequence of Azospirillum brasilense CBG497 and comparative analyses of Azospirillum core and accessory genomes provide insight into niche adaptation. Genes 3:576-602

Yahalom E, Okon Y, Dovrat A (1990) Possible mode of action of Azospirillum brasilense strain $\mathrm{Cd}$ on the roots morphology and nodule formation in burr medic (Medicago polymorpha). Can J Microbiol 36:10-14

Yaxley J, Ross J, Sherriff L, Reid J (2001) Gibberellin biosynthesis mutations and root development in pea. Plant Physiol 125:627-633

Zeevaart J (1999) Abscisic acid metabolism and its regulation. In: Hooykaas P, Hall M, Libbenga K (eds) Biochemistry and molecular biology of plant hormones. Elsevier Science, Amsterdam, pp 189-207

Zhu JK (2002) Salt and drought stress signal transduction in plants. Annu Rev Plant Biol 53:247-273

Zimmer W, Roeben K, Bothe H (1988) An alternative explanation for plant growth promotion by bacteria of the genus Azospirillum. Planta 176:333-342 